\title{
SOCIAL EMBEDDEDNESS AS A TRIGGER OF BUSINESS TOURISM COOPERATION
}

Cooperation between individual actors from a given tourist destination is a necessity under contemporary conditions. Its establishment and development can be triggered by many factors, and the social embeddedness of tourism entrepreneurs in the local community can be considered one of them. This factor is likely to be of special importance as social aspects are very important in the tourist sector. The aim of the paper is to present and assess the impact of social embeddedness on business cooperation in dyads and networks. The analysis was conducted using the case of a partnership structure in the south of Poland. To achieve the research aim, Social Network Analysis (SNA) was employed. The paper exploits an approach very rarely used in tourism empirical research, which combines two types of SNA- qualitative and quantitative. The research confirmed the role of social embeddedness as a trigger for cooperation in a tourist destination.

Keywords: social embeddedness, cooperation, dyads, networks, SNA

DOI: $10.15611 /$ aoe.2020.1.14

\section{INTRODUCTION}

Given today's tourist market conditions, cooperation between individual actors from a given tourist destination is a necessity (Baggio, 2011; Gursoy, Saayman and Sotiriadis, 2015). Partners decide to cooperate - in dyads (with another partner) or networks (with two or more entities) - for different economic reasons: entering new markets, reducing costs of activity, having stronger bargaining power in dealing with market contractors, lobbying on issues important for a given group of entities or the entire destination, etc. (Beritelli, 2011; Czernek, 2013; Fyall, Garrod, 2005; Timothy, 1998; Wang, Fesenmaier, 2007).

The establishment and development of such cooperation can be triggered by many factors, one of them being the social embeddedness of tourism entrepreneurs in the local community. The originator of the social embeddedness concept was M. Granovetter (1985). However, he did not formulate a strict definition of the phenomenon, yet embeddedness may be understood,

\footnotetext{
* Department of Management Theory, University of Economics in Katowice.

** Department of Money and Banking, Poznań University of Economics and Business.
} 
following Uzzi (1999, p. 482), as the "degree to which comercial transactions take place through social relations and networks of relations that use exchange protocols associated with social, non-commercial attachments to given business dealings".

Granovetter claimed that all economic decisions and actions taken by entrepreneurs are embedded in the social context in which those entrepreneurs operate. Thus, the social context in which an entrepreneur operates (the history and background of particular interpersonal relationships, the entrepreneur's origin, length of time of his/her activity in a particular community, etc.) affects - possibly positively or negatively - her/his economic decisions, also those connected with cooperation. Here, Granovetter considers two aspects (dimensions) of embeddedness: relational social embeddedness (relations between two individual actors) and structural social embeddedness (relations between an actor and the social network in which the actor is embedded). These dimensions can be considered in the context of, respectively, dyad and network business cooperation - the fact that an actor is relationally and/or structurally embedded will influence the actor's economic decisions on whether and with whom to start such cooperation and how to engage in it.

The influence of social embeddedness on cooperation in tourism destinations is likely to be of special importance, as social aspects are very important there. Relations in those destinations often concern small communities with a number of direct personal relationships between entrepreneurs, who have to cooperate if they want to satisfy the complex and diverse needs of tourists. It is therefore surprising that the idea of social embeddedness and its role in business cooperation has not been more broadly applied in tourism research. So far, only a few papers have directly analysed the role of social embeddedness in the tourism sector (Czernek, 2014; Ingram, Roberts, 2000; Jack, Anderson, 2002). In the literature, these social bonds and their role in cooperation are usually stressed with no direct reference to Granovetter's concept. Frequently the social embeddedness of tourism entrepreneurs has been referred to indirectly by analysing aspects such as: interpersonal relationships (Beritelli, 2011; Jack, Anderson, 2002), communication (Saxena, 2006), trust (Bramwell, Lane, 1999; Czernek, Czakon, 2016; Grangsjo, 2006; Munar, Jacobsen, 2013; Nunkoo, Ramkisson, 2011a, 2011b; Strobl, Peters, 2013) the specificity of small and medium sized enterprises (SMEs) (Czernek 2017; Ritchie, Ritchie, 2002), or the asymmetry of power and authority (Nunkoo, Ramkisson, 2011a; Reed, 1997), etc. Moreover, the results presented in the literature often lack a more detailed, thorough analysis of 
the social context, including the concrete interpersonal relationships of the researched entities.

Such research should focus on how social embeddedness could be important as a factor triggering business cooperation between tourist entrepreneurs. Thus, the aim of the paper is to present and assess the impact of social embeddedness (relational and structural) on business cooperation in dyads and networks. The analysis was conducted using the example of the 'Wisła Tourist Organization' (WTO) - a partnership structure functioning in a mountain municipality in the south of Poland. To achieve the aim of the paper Social Network Analysis (SNA) was employed. This approach is very rarely used in tourism empirical research (see the review by MerineroRodríguez and Pulido-Fernández, 2016), as the authors combine two types of SNA - qualitative and quantitative.

The paper consists of five parts. The first lays the theoretical foundations by reviewing the literature on social embeddedness and its role in cooperation in different sectors of economy. It also reviews previous empirical works where this role was directly or indirectly analysed regarding the tourism sector. The second part presents the research methodology and characterizes the SNA approach, stressing its usefulness in analysing cooperative relationships. The third part shows the research results on the role of social embeddedness in entering business cooperation among the entities researched. Then the results are discussed with reference to the existing literature and, finally, the authors present the research conclusions, practical recommendations and the research limitations.

\section{SOCIAL EMBEDDEDNESS, ITS FEATURES AND INFLUENCE ON COOPERATION - LITERATURE REVIEW}

Social embeddedness, one of the most important elements of so-called New Economic Sociology (Gibbons, 2005), links to some extent the economic and sociological approaches. In Granovetter's concept, business relationships depart from pure "market" patterns, aiming only at profit maximization by individual actors (behaving like the neoclassical homo oeconomicus). Granovetter clearly states that economic models constructed in this way, without any social context, make economic analysis superficial and incomplete. Only by taking this context into account is a researcher fully able to understand economic decisions and actions (see also: Arrow, 2000 and Dequech, 2003). 
However, the author simultaneously criticizes the homo sociologicus model developed by sociologists, which assumes that actors' decisions and activities are under the absolute impact of social norms, values, etc. Granovetter (1985, p. 487) claimed that "actors do not behave or decide as atoms outside a social context, nor do they adhere slavishly to a script written for them by the particular intersection of social categories that they happen to occupy. Their attempts at purposive action are instead embedded in concrete, ongoing systems of social relations".

According to Granovetter $(1985 ; 1993 ; 2005)$, both perspectives that should be combined as purely economic goals are accompanied by noneconomic ones, connected with the social context. Apart from profit, the decisions of actors are also determined by their knowledge about each other and attitude to each other (liking, aversion, closeness, trust, etc.). The social structure is especially important in the information flow in the market. The information is much more reliable if it comes from a known source - from an actor with whom an information receiver is socially bound. At the same time, frequent and regular contact between actors leads to trust between them, which also makes information transfer easier. Thus, the transaction costs of such an information transfer are lower and the quality of information better (Granovetter, 1985).

In addition to the impact of social bonds on information transfer, Granovetter (1985) also claims that interpersonal relationships can influence economic activities because they may constitute an important source of rewards and punishments for given market behaviour. Moreover, partners with interpersonal relationships believe that a partner will not behave opportunistically. Finally, Granovetter points out that social relationships stimulate creativity and innovativeness by reducing the transaction costs of activities.

Having considered this, one could state that the social embeddedness concept draws researchers' attention to a brand new area of deliberation, where human action is perceived as determined by the network of social relationships in which a given entity functions (Zukin and DiMaggio, 1990), with all the potential benefits and disadvantages of such a situation. Therefore the concept began to be exploited in many different research fields (see: Scheme1).

Importantly, many other concepts of embeddedness have been developed in the subject literature in addition to the two postulated by Granovetter (e.g. cognitive, cultural, political or structural embeddedness), And thus the levels of analysis were also different - not only were individual people or 
companies analysed, but also branches, non-profit organizations or even whole governments (Zukin, DiMaggio, 1990). Many authors have expanded Granovetter's concept, identifying at the same time many advantages of social embeddedness such as: access to key resources, costs and risk reduction, informational benefits, etc. (Burt, 1992; Mizruchi, Stearns, 1994; Useem, 1979; Uzzi, 1997; Webster, Wind, 1972). Emphasis has also been placed on the importance of informal social systems for coordination and cooperation (Piore, Sabel. 1984; Ring, Van de Ven, 1992), where contracts are perceived as more socially binding than legally (Jones, Hesterly, Borgatti, 1997).
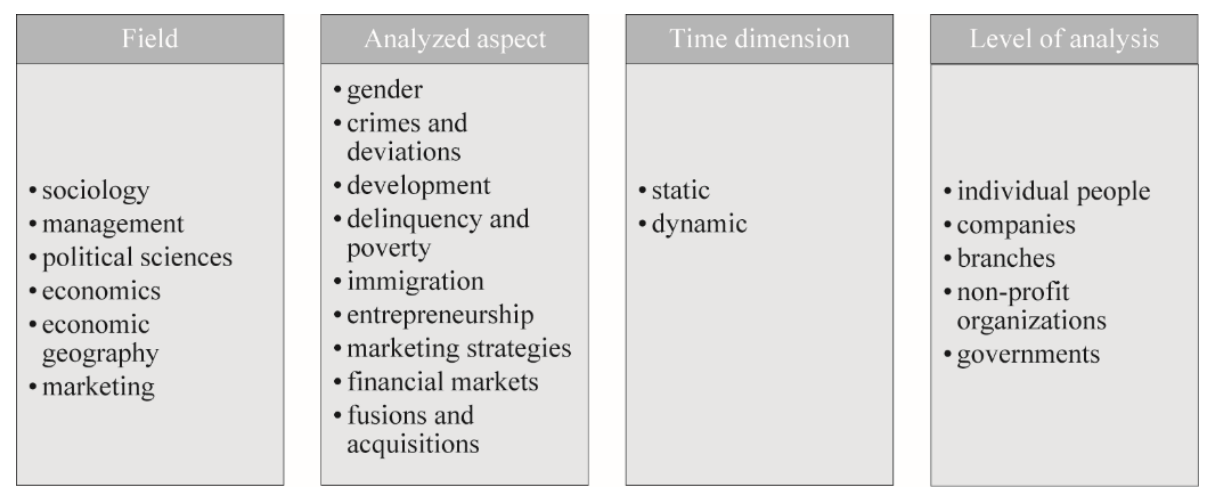

Scheme 1. Dimensions of social embeddedness analysis

Source: own elaboration based on the literature review.

However, considering the previously highlighted role of social aspects in economic decisions, it is surprising that the social context has not been the subject of more intense empirical research. This also refers to empirical works on tourism, where social embeddedness might be of a special significance, as the sector is dominated by SMEs which offer complementary goods and services and often operate in small territories where entities usually know one another (see e.g. Czernek, 2017; Jack and Anderson, 2002; Smith, 2006). Thus, in this case, the establishment of cooperative relationships and the role of the social context appears to be crucial in the process.

Among the authors conducting research on the role of social structure and interpersonal relationships in tourism activity there are Beritelli (2011), Hibbert, Dickinson, Curtin, 2013; Dredge (2006), Pavlovich (2003), Rachela, $\mathrm{Hu}$ (2010), Scott et al. (2008) and Tinsley and Lynch (2001). However, the 
researchhas addressed the issue of social embeddedness in economic decisions mainly indirectly - by taking into consideration some social factors (see Scheme 2). For example, Getz and Jamal (1994), Gill and Williams (1994), Robson and Robson (1996) and Reed (1999), use the concept of the so-called community planning of tourist destination development, with the participation of the local community and local institutions. This approach was also used by Beritelli (2011, p. 610) who claims that community planning approaches constitute the embodiment of all that happens in the daily life of tourist societies: "people meet in their professional environment or privately; talk about issues and about other people; form a view on something; have disputes or form friendships; and make decisions at a personal and institutional level". Beritelli (2011) indirectly stresses the role of actors' social embeddedness by claiming that in the tourism sector, actors cooperate with one another independently of formal, professional and political ties. Their cooperation occurs on the grounds of mutual trust and understanding enforced by effective and frequent communication. Hence, to develop cooperation or to undertake joint actions, the entities have to pay attention to interpersonal ties formed previously.

Generally, there is a lack of papers in which the concept of social embeddedness of tourism economic actions is directly applied. There are a few such papers, one is the work of Jack and Anderson (2002). They analyse the positive and negative results of social embeddedness amongst entrepreneurs in rural areas in the Highlands in Scotland. They stress the benefits of social embeddedness as: better knowledge about local market conditions and local economic potential which can stimulate private entrepreneurship, lower costs of information transfer, and activities conducted thanks to trust between socially embedded partners.

Ingram and Roberts (2000) also refer directly to the concept of social embeddedness. They analyse friendship relations among managers of hotels in Sydney. These relations, as the authors show, helped managers to prevent price wars - the more coherent a given group of friends among the hotel managers was, the better the cooperation results.

Czernek (2014), and Czernek and Mitrega (2016) analyse the influence of social embeddedness on the establishment, development and results of tourism cooperation. The authors identified different sources of social embeddedness (including the place of entrepreneur's origin, relations from former workplaces, being members of clubs, organizations, religious beliefs, etc.) and factors positively and negatively influencing business cooperation. The former included, for instance, lower transaction costs (thanks to a reduction 

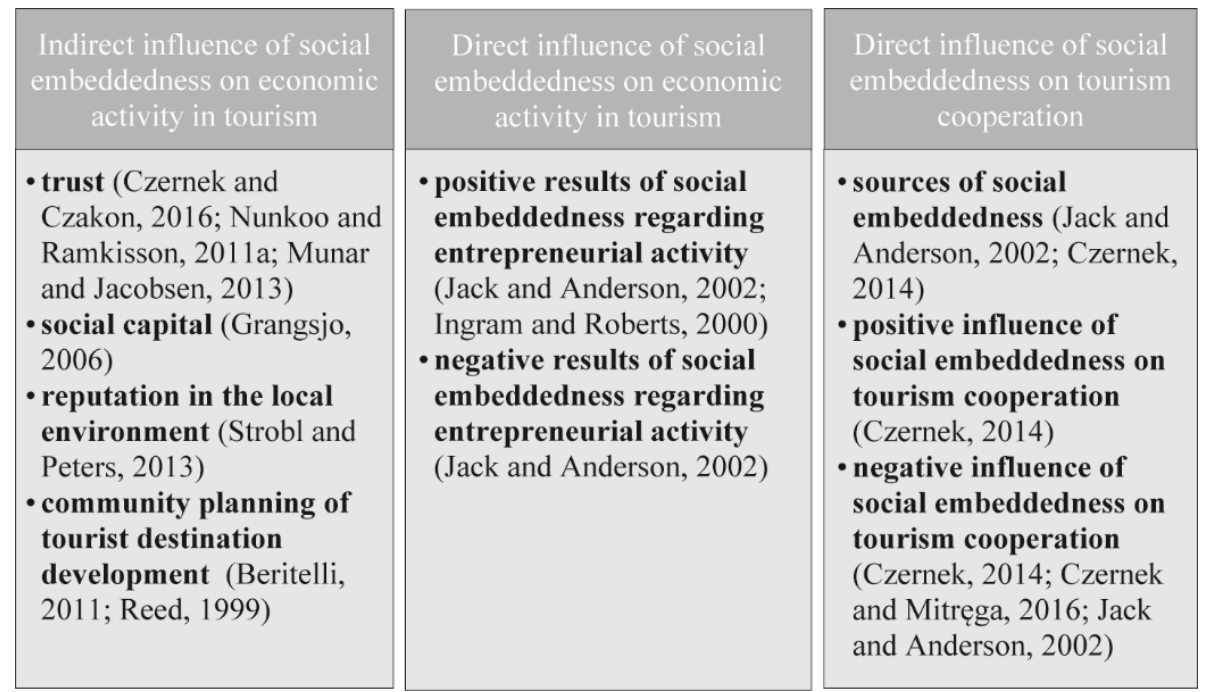

Scheme 2. Direct and indirect influence of social embeddedness on tourism activity summary of previous research

Source: own elaboration.

in costs of transferring information about cooperation amongst familiar partners), trust between entities, possibility of a more effective transfer of information by using social relations, etc. Among the latter factors were, for example, being closed to potential outside partners - cooperating with known partners instead of unknown entities (building hermetic societies), lower innovativeness of activities, putting economic aims after social ties (prioritising too far-reaching social relations instead of economic issues) etc. (Czernek, 2014; Czernek and Mitręga, 2016). This analysis, however, was only explorative and qualitative, and created a starting point for future research on the topic.

The review of the literature shows the need to deepen knowledge about the direct influence of social embeddedness on tourism cooperation. The authors argue that the use of Social Network Analysis and combining the quantitative and qualitative approaches (relatively rarely combined in empirical tourism research and not used at all regarding the analysis of the social embeddedness issue) can be very useful when analysing those issues. 


\section{RESEARCH METHODOLOGY}

\subsection{Social Network Analysis as the main research tool - justification}

In a network approach, the researcher is interested mainly in relations (ties) occurring between entities (actors/nodes) or their groups. These relations create a network structure. Thus, the approach appears to be extremely useful in analysing social embeddedness issues, as the social relationships emerge just in the network of a given community/region.

In more detail, SNA can be useful to analyse the role of social embeddedness in business cooperation due to the following reasons. Firstly, it can be applied to identifying and researching different types of relationships (including formal and informal relationships) between entities (Casanueva, Gallego, García-Sánchez, 2016; Wasserman, Faust, 1994). In network analysis, interpersonal relationships based on social norms such as trust, understanding, etc., are not only identified, but are perceived as very important (Dredge, 2006; Scott, Baggio, Cooper, 2008).

Secondly, SNA allows for the analysis of identified relations from different perspectives (of a particular actor or a network as a whole). This can be very important to understand the social context in which researched entities operate, and its influence on their decisions. Moreover, the cooperation can be exploited at the level of both dyads and the whole network (Scott, Baggio, Cooper, 2008).

Thirdly, network analyses of relations in the tourism sector are more and more popular (see reviews of network research in the tourism sector, e.g.: Baggio, 2017; Merinero-Rodríguez, Pulido-Fernández, 2016). However, as noted by Casanueva et al. (2016), who, incidentally, argue that SNA can be far more exploited intourist cooperation, still today "the number of articles that employ these methods in a field as wide as tourism is very low [...]. [Moreover] almost a third of the works are not linked to studies on tourism activity, but on the analysis of the investigation itself" (p. 1204) (they provide bibliometric analyses). As one of reasons forsuch a situation the authors mention problems with collecting primary relational data.

Fourthly, empirical works which exploit SNA are usually based on the qualitative (e.g. Dredge 2006; Pavlovich 2003) or quantitative approach (e.g. Beritelli, 2011; Scott, Baggio, Cooper, 2008; Racherla, Hu, 2010; Shih, 2006). However, it is highly recommended to combine both of them (Casanueva et al., 2016; Domínguez, Hollstein, 2014; Kelman et al. 2016). According to Baggio (2017), "in fact, despite the many discussions and 
distinctions, the two views [qualitative and quantitative] are not only complementary, but practically mandatory if we want to fully understand the systems and be able to draw meaningful outcomes" (p. 124).

Quantitative SNA enables to calculate some network parameters - the structural features of networks (e.g. centrality, reciprocity, density, etc.), and characterize and visualize the network of relations between individual actors and the features of the network. It also allows to conduct a dynamic analysis of a network by comparisons of the above parameters made at different points in time. A qualitative approach, in turn, helps to explain why the structure has its particular form, and how relations within the structure influence its activity. This is extremely important because each relationship is a specific one - with its own history and social context (Granovetter, 1985). Thus, qualitative SNA allows for a better understanding of what happens in the network (Jack, 2010; Wasserman and Faust, 1994). Hollstein (2014) claims that mixed methods can provide a specific contribution to investigating social networks, especially in three areas: (1) a detailed description of a network, network practices and interpretation; (2) network effects, and (3) network dynamics. With regard to the issue of social embeddedness, providing mixed social network methods seems to be particularly useful for application to the first and the second types of benefits. It allows for a better understanding of how individuals position themselves in relation to their social context, and of the patterns of actors' contacts regarding business cooperation. With regard to network effects, mixed methods can contribute to a better understanding of what mechanisms and conditions (one of them may be social embeddedness) are involved when producing certain network outcomes, e.g. business cooperation. Furthermore, mixed network research is also useful for researching complex phenomena and those for which prior knowledge of the field and of the relevant context factors exists, but is still incomplete (Wald, 2014).

Thus, the authors of this paper argue that only such a complementary approach will allow for full understanding of the issue analysed -in this case, the role of social embeddedness as a trigger of tourism cooperation. All the arguments justify using SNA (quantitative and qualitative) as an empirical tool for achieving the aim of the paper. The use of such a mixed SNA approach, together with social embeddedness, a rarely used concept in tourism literature, creates, according to the authors, added theoretical and methodological value. 


\subsection{Case study selection}

The research results are part of a broader research project aimed at evaluating cooperation within one of the Polish Destination Management Organizations located in the south of Poland, called the 'Wisła Tourist Organization' (WTO). The case study method was used, and the WTO was purposefully chosen by the researcher. The organization was chosen for a few reasons.

Firstly, it is located in Wisła - a well-known tourist destination in Poland. This is a popular mountain destination with many winter and summer attractions, based on active tourism (mainly skiing). Wisła is a relatively small town, with a population of 11,810 and an area of $110.26 \mathrm{~km}^{2}$. This allowed the researcher to assume that it would be possible to identify the phenomenon of social embeddedness amongst Wisła entrepreneurs and analyse this in relation to business cooperation.

Secondly, the organization unites those entrepreneurs who are the most important and the most engaged in tourism development in Wisła, with one of the WTO members being part of Wisła local authorities.

Thirdly, the WTO brings together a relatively large number of tourist entrepreneurs- at the time when the research was conducted it was 55 members (while in this type of organization in Poland there were on average 37 members). There exists a high level of interdependence between WTO members since these are entrepreneurs serving complementary goods and services such as accommodation, transport, catering, souvenirs, tourist attractions etc. This allowed the researcher to assume that in addition to their joint membership in the WTO (network cooperation), they would also be engaged in dyadic business cooperation with each other.

Fourthly, the WTO has a few years of experience in tourist sector cooperation aimed at promoting Wisła as an attractive tourist destination. For the last nine years the organization has conducted an array of promotional activities, including workshops and seminars for its members, to encourage tourists to visit the town. During that time some informal relationships between WTO members could have been developed.

Fifthly, the researcher had previous knowledge about the context of this organization (its establishment and development) and about the process of tourism development in Wisła. This knowledge was obtained thanks to previous longitudinal research conducted in this area. This allowed for a better access to interviewees, and a better understanding of the issues analysed. 
From July 2013 until December 2014, semi-structured interviews were conducted with 48 members of the WTO. These were owners or managers of companies offering different types of goods and services connected to tourism - their detailed characteristics are presented in Table 1 in the Appendix. The interviewees were people responsible in their firms for business cooperation with other companies in Wisła or outside the municipality. Seven of the interviewees did not agree to take part in the research, although several attempts were made by the researcher to convince them to do so. A short telephone call or personal conversation with those seven entrepreneurs revealed that they were going to resign from their membership in the WTO, and that was one of the reasons why they were not engaged in WTO activities, had no knowledge about those activities, and did not want to take part in the research.

The research results are part of a broader research project where the 'Wisła Tourist Organization' was treated as a network of relationships between its actors - WTO members. Interviewees were asked closed and open questions about their activity in the WTO in order to evaluate the density and content of relationships between members of this organization. This was aimed at assessing the organization in terms of its role as a platform for its members to build (among other types of relationship) dyadic business cooperation. This aim was one of the most important purposes of the WTO, written in the statute of the organization. The organization's initiators assumed that formal membership of the WTO would enable its members to gain knowledge about one another, their product offer, location, etc. This could have been done by joint promotional materials, direct contacts during WTO meetings or organized promotional events, etc.

Therefore each interviewee was asked about the existence of such dyadic business cooperation between him/her and every other member of the network (WTO). If they declared the existence of such a cooperation, they were also asked whether formal membership in the WTO together with their business partners directly contributed to establishing such dyadiccooperation. When answering this question, only some of the interviewees stated that their business cooperation was the result of joint formal membership in the WTO. Most of them declared that it was the result of interpersonal relationships that they had established with a particular WTO member even before they became WTO members. Moreover, they claimed that these interpersonal relationships were also very important in the process of making 
the decision whether to join the WTO. This resulted in some additional open-ended questions asked about interpersonal relationships with other WTO members, with the aim to analyse their role as a trigger of dyadic and network business cooperation.

When interviewees declared business cooperation with a particular WTO member, they were asked about the content of this relationship (what was the subject of this cooperation) and its context (how and why it was established, and why with this particular partner). When they pointed out the role of interpersonal relationships in making the decision on entering the WTO, they were asked to describe the context of becoming such a WTO member. With the interviewees' permission, the interviews were recorded.

\subsection{Research procedure}

The research analysis was conducted in two steps (see Scheme 3), both based on a combination of quantitative and qualitative analysis. The first step was performed from the perspective of the network as a whole, while the second was from the perspective of particular actors. In the first step, two zero-one matrixes were created - for those interviewees who declared that their business cooperation with other WTO members was a result of their joint formal membership in the WTO (formal relationships), and for those claiming that this cooperation was the result of previous interpersonal relationships between those entities (informal relationships). The seven actors who did not participate in the research were removed from the matrixes, resulting in a 48 row x 48 column grid. Each matrix represented a different type of network - a network of entities cooperating in a dyad thanks to joint formal membership in the WTO, and a network of entities cooperating thanks to their former interpersonal relationships. The material collected allowed for the identification of a structure of relationships in both networks, afterwards visualized in the form of graphs. This visualization was performed with the use of the UCINET software application. Then, using SNA parameters (density, reciprocity, network centralization, diameter, etc.) the cohesion of both networks was compared - see Table 1 .

In those networks which are more cohesive, the diffusion of resources is higher - for example, actors can relatively easier, faster and with no high transaction costs, give and receive resources - e.g. information, goods and services, transactions, etc. Such cohesive networks can therefore generate higher benefits for its actors. 
Table 1

SNA cohesion measures used in the research analysis

\begin{tabular}{l|l}
\hline \multicolumn{1}{c|}{ Parameter } & \multicolumn{1}{c}{ Parameter characteristics } \\
\hline Density & $\begin{array}{l}\text { Calculated as a quotient of the number of relationships existing in the } \\
\text { network, to the entire number of all possible links (everyone with } \\
\text { everyone). This is an important property of a network structure, because } \\
\text { dense networks, thanks to similar systems of communication and more } \\
\text { intensive change of information, ensure circulation of norms and values, } \\
\text { and create joint expectations regarding other entities' behaviours (Olivier, } \\
1991 ; \text { p. 171). }\end{array}$ \\
\hline Reciprocity & $\begin{array}{l}\text { A measure of the likelihood of vertices in a directed network to be } \\
\text { mutually linked. }\end{array}$ \\
\hline Components & $\begin{array}{l}\text { Number of connected actors in the network (actors who are not peripheral } \\
\text { ones). }\end{array}$ \\
\hline $\begin{array}{l}\text { Degree } \\
\text { centralization }\end{array}$ & $\begin{array}{l}\text { The level of organization of activities regarding cooperation in the } \\
\text { network. }\end{array}$ \\
\hline Diameter & The shortest distance between the two most distant nodes in the network. \\
\hline $\begin{array}{l}\text { Average } \\
\text { distance }\end{array}$ & $\begin{array}{l}\text { Average number of steps along the shortest paths for all possible pairs of } \\
\text { network nodes. }\end{array}$ \\
\hline Connectedness & The general level of connections of actors in the network. \\
\hline Fragmentation & The level of isolation of actors in the network. \\
\hline
\end{tabular}

Source: own elaboration.

When the content of relations in a network is a business cooperation, it can be stated that such cooperation can be more effective and can generate higher benefits for its members and the network (destination) as a whole. Thus, it was assumed that if a network of business dyadic cooperation based on interpersonal relationships was more coherent than one based on formal relations built through joint membership in the WTO, it would mean that interpersonal relationships are a better source of building and developing business dyadic cooperation than formal membership in an organization. At this first step of analysis, the conclusions regarding the role of formal and informal relations as a trigger of business cooperation were also formulated based on interviewees' statements (qualitative analysis).

Next the second step of analysis began. Assuming that thanks to WTO membership some WTO members could establish personal ties with other WTO participants, and that it could be further used to start dyadic business cooperation, the results obtained earlier for both networks were aggregated and one network of business cooperation was created. In this second step, the aim was to identify the most engaged and the least engaged entities in 
business cooperation (central and peripheral actors). This would mean that the most active actors in business cooperation (central actors) could be identified not only as those with a lot of interpersonal relationships in the local community (established before WTO membership), but also those who managed to build such bonds thanks to WTO membership. In order to identify such central actors, centrality measures were used, i.e. (Freeman, 1978): degree, betweenness and closeness centrality - see Table 2.

Table 2

Centrality measures used in the research

\begin{tabular}{l|l}
\hline Centrality & \multicolumn{1}{|c}{ Allows for identification of the most important nodes in the graph. } \\
\hline Degree & $\begin{array}{l}\text { Refers to the number of direct connections (incoming and outgoing contacts) } \\
\text { maintained by an actor with other nodes in the network. The central node has } \\
\text { the highest number of contacts with other members of the network and can } \\
\text { therefore play the coordinator and gatekeeper role in the network. }\end{array}$ \\
\hline Betweenness & $\begin{array}{l}\text { Betweenness centrality measures an actor's ability to mediate among others, } \\
\text { or their groups in the network - this kind of central actor connects different } \\
\text { actors or their groups in the network (a broker role). }\end{array}$ \\
\hline Closeness & $\begin{array}{l}\text { Determines the distance between an actor and other actors in the network. The } \\
\text { central actor according to this measure is the one who combines the shortest } \\
\text { aggregated distance between him and all other actors in the network. }\end{array}$ \\
\hline
\end{tabular}

Source: own elaboration.

A centrality parameter was also used to identify peripheral actors - i.e. those who were not engaged in business cooperation at all or were engaged relatively poorly, after which qualitative analysis was conducted. This made it possible to determine whether the identified central actors were embedded in the social network, and if this social embeddedness or its lack determined the central/peripheral position they occupied ${ }^{1}$ (see Scheme 3).

\footnotetext{
${ }^{1}$ Occupying a central position in such a network could be the result of different issues. Obviously, an actor can have a lot of interpersonal relationships with other actors, but this does not necessarily have to be the reason for being a popular partner in business cooperation. For example, the main reason could be the fact that the entity represents a unique attraction in the municipality. Moreover, entities can know each other personally, but because of certain reasons have no need of business cooperation, etc. (in such a situation they can be peripheral actors in a network of business cooperation, however, at the same time can sustain a lot of interpersonal relations with other entities). Hence, deep qualitative analysis of the positions of central and peripheral actors was highly necessary here.
} 


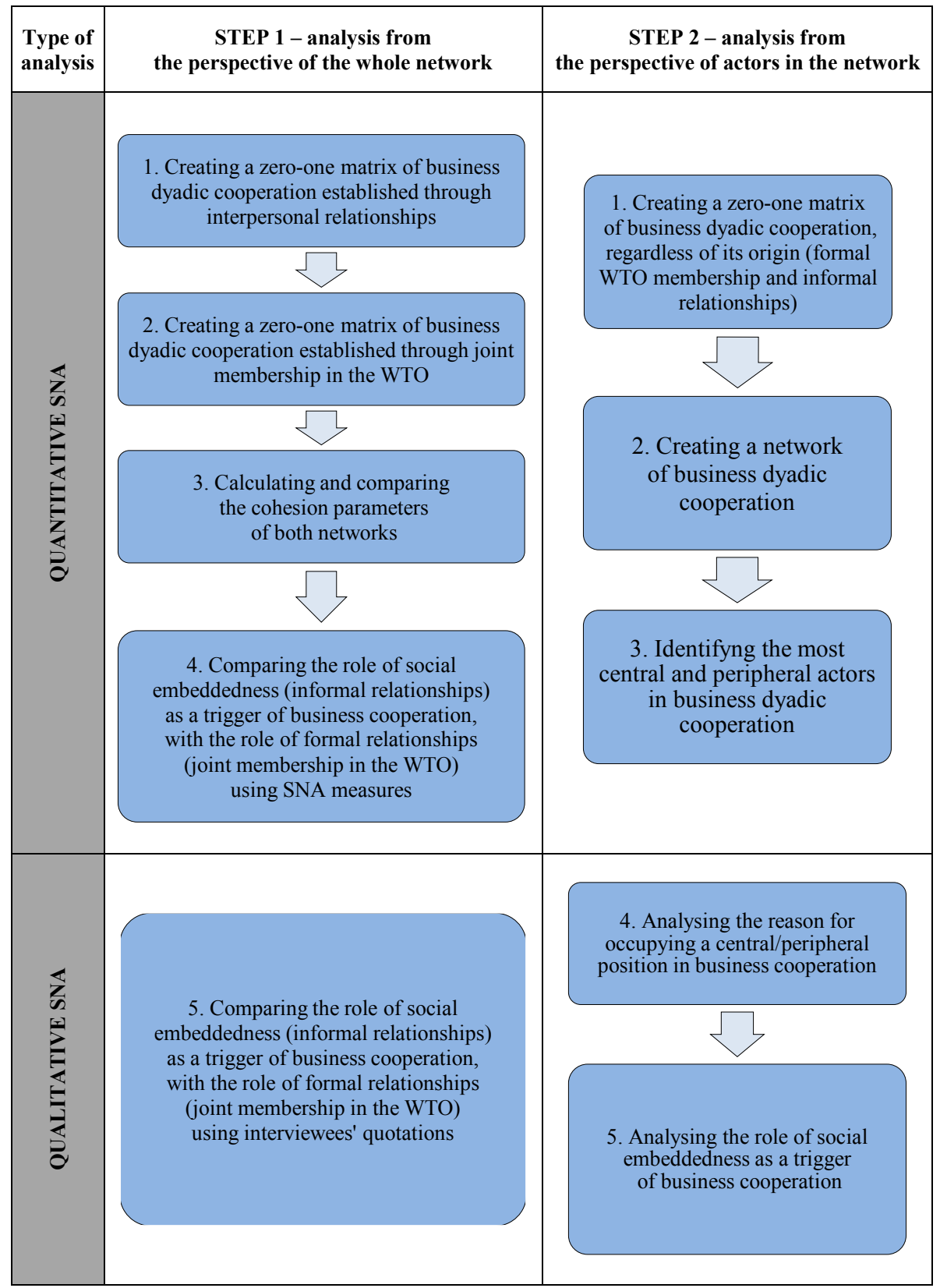

Scheme 3. Research procedure description

Source: own elaboration. 
Interviewees' direct opinions (quotes) were transcribed and analysed. Qualitative data analysis consisted of three concurrent flows of activity (Miles and Huberman, 1994):

- data reduction - transcribing the whole interviews (including digressions) and creating case cards for all 48 interviewees, then coding the whole material;

- data display - codes reflecting the positive influence of social embeddedness on entering into and developing dyadic and network cooperation were particularized and ordered;

- data verification - data representing the role of social embeddedness in dyadic and network cooperation were analysed and verified using the literature results regarding the concept of social embeddedness.

To increase the level of research trustworthiness (Guba, 1981), all procedures in the research were documented and a detailed protocol was set up, also full transcripts, definitions of codes and their applications were created and checked (Saldaña, 2009).To code interviews, the authors utilized Atlas.ti v. 7.0 - qualitative data research software. Interview transcription allowed quotes to be added to the text in order to scientifically validate the analysis. Qualitative analysis, together with a visualization of relationships in the network, provided a more comprehensive and rich picture of relationships in the WTO. It also allowed for a better understanding of those relationships, especially the role of social embeddedness in dyadic and network cooperation.

\section{RESULTS}

\subsection{Analysis from the perspective of the whole network - step 1}

In order to assess the role of interpersonal relationships in entering dyadic business cooperation, these social relationships were compared to formal ones (joint formal membership in the WTO) as a potential source of such cooperation. The answers of interviewees to the question whether they established dyadic business cooperation thanks to joint formal membership in the WTO, or due to interpersonal relationships built before joining the organization, allowed the development of binary matrices reflecting networks of each of the above two types of relationships. It was then possible to analyse and compare both types of networks from the perspective of the network as a whole (first step of analysis - see Scheme 3). 
The research results showed that to establish dyadic business cooperation, the role of social embeddedness was more significant than partners' formal membership in the WTO. Cooperation based on personal relations was maintained on average with seven other network partners, while one established thanks to joint formal membership in the WTO only with three other partners. This is even more interesting when one takes into account the fact that allowing WTO members to establish such dyadic business cooperation constitutes one of the main statutory goals of the WTO organization.

As the research showed, the sources of personal relationships were very diverse. These were, for example: the common (Wisła) origin of the actors, a long stay in the municipality (e.g. 10 years of conducting business or more), neighbourhood and close location to each other, family ties, established friendly ties, for example, at school or in previous jobs. The fact that interviewees felt socially embedded was not only confirmed by them during interviews (they could relatively easily say if they feel a part of the local community and whether they know its members well or not), but was also visible in the way they described relations in the local community (structural embeddedness) and with particular entrepreneurs (relational embeddedness). Often, they used only the first names of company owners or managers, some knew only the maiden name of some female entrepreneurs, and spoke about them as they would about colleagues or even friends. A few even claimed that some of them were closer or more distant relatives.

The more significant role of interpersonal (informal) relationships in comparison to formal ones in business cooperation was also confirmed by calculating different SNA parameters (e.g. density, reciprocity, degree centralization, diameter, average distance, connectedness, fragmentation, etc.) for both types of networks (see Table 5). These parameters were used to assess and compare the cohesion of each type of network.

First, the density of both networks was calculated and analysed. The comparison of the density parameter of both networks is presented in Table 3.

Table 3

Density of business cooperation built through WTO membership or former interpersonal relations

\begin{tabular}{l|l|c}
\hline \multicolumn{1}{c|}{ Type (content) of relation } & \multicolumn{1}{c|}{ Source of relations } & Density (max $=1)$ \\
\hline \multirow{2}{*}{ Business cooperation } & Formal WTO membership & 0.06 \\
\cline { 2 - 3 } & Former interpersonal relations & 0.15 \\
\hline
\end{tabular}

Source: own work based on research. 


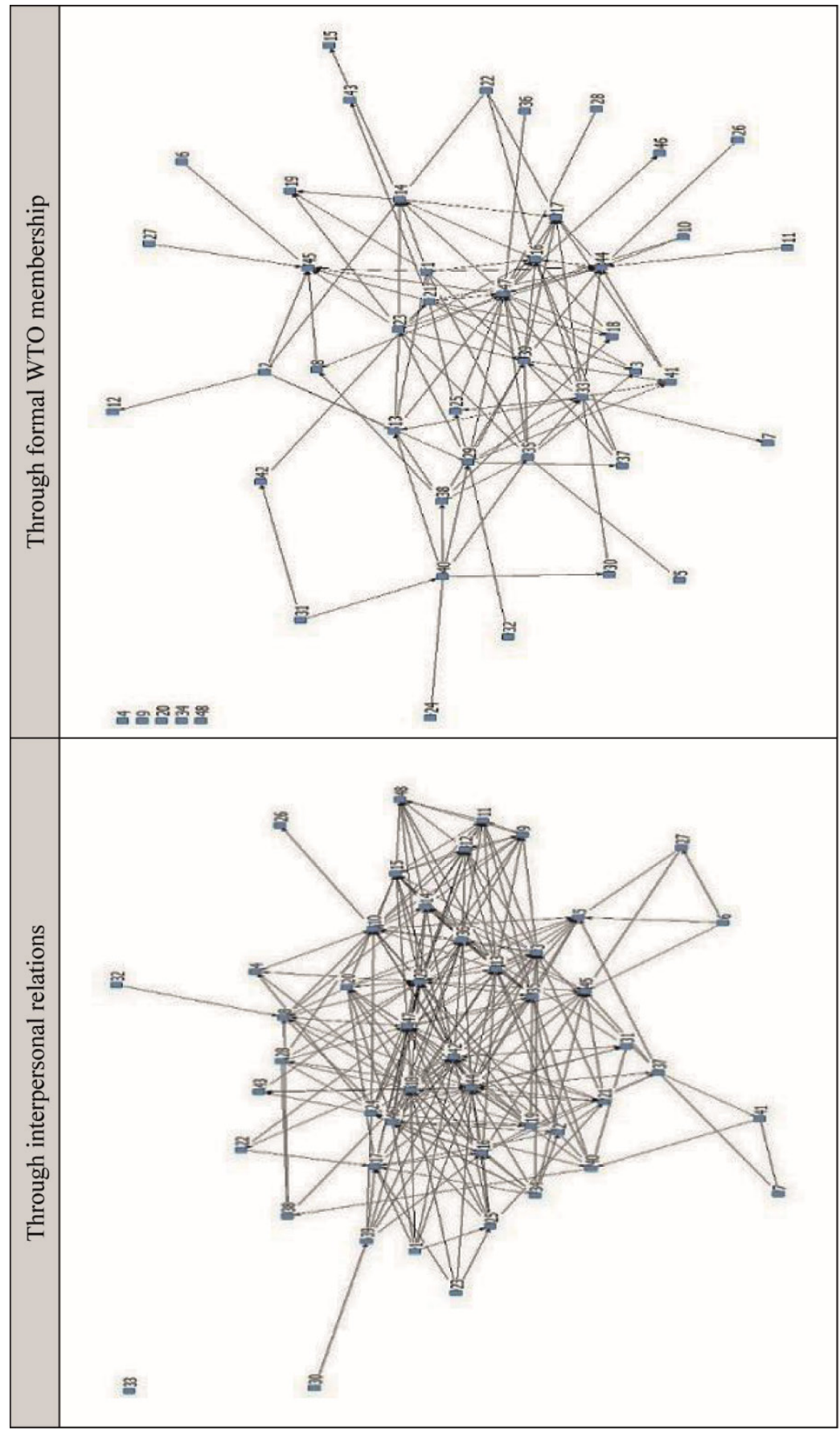

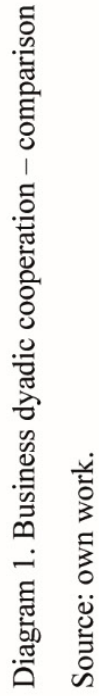


The network of cooperation established through interpersonal relationships was denser. As can be seen, the density of the network reflecting business cooperation established through formal membership in the WTO was about $6 \%$, while the second was more than twice that figure $-15 \%$. A visual comparison of both networks is shown in Diagram 1. It shows that networks built thorough interpersonal relationships ensure the faster diffusion of resources in a network.

Another calculated SNA parameter was the level of reciprocity of relations in a network. Business cooperation built through interpersonal contacts was more reciprocal than that derived from formal WTO membership (see Table 4 and the visualization of relations in both types of networks shown in Diagram 2 - the reciprocal ties are red and the unreciprocated black). This means that when business cooperation was built through interpersonal relationships (instead of WTO membership), the actors who mentioned other entities as their partners were also more often pointed out by those partners as their business cooperators.

Table 4

Reciprocity of relations of WTO members establishing dyadic business cooperation built through formal WTO membership and interpersonal relations

\begin{tabular}{l|c|c}
\hline \multicolumn{1}{c|}{ Type of arcs } & $\begin{array}{c}\text { Cooperation established } \\
\text { through interpersonal relations }\end{array}$ & $\begin{array}{c}\text { Cooperation built through } \\
\text { formal WTO membership }\end{array}$ \\
\hline Reciprocated & 190 & 32 \\
\hline Unreciprocated & 159 & 93 \\
\hline All arcs & 349 & 125 \\
\hline Arc reciprocity & $\mathbf{5 4 \%}$ & $\mathbf{2 5 . 6 \%}$ \\
\hline
\end{tabular}

Source: own elaboration, based on research with the use of the UCINET application.

Moreover, as other calculations showed, the cooperative network originating informal joint WTO membership was very fragmented - it consisted of 33 unconnected elements (components), whereas the network reflecting business cooperation based on interpersonal relations had nine components. A greater coherence of the network based on interpersonal relationships was also demonstrated by the other parameters listed in Table 5. This was a higher level of centralization in terms of the level of organizing cooperation activities in a network (for cooperation established thanks to interpersonal relationships it was 0.460 and for WTO membership 0.231). Moreover, in the case of cooperation based on personal relationships, the mutual access of actors to one another was greater (lower diameter and 


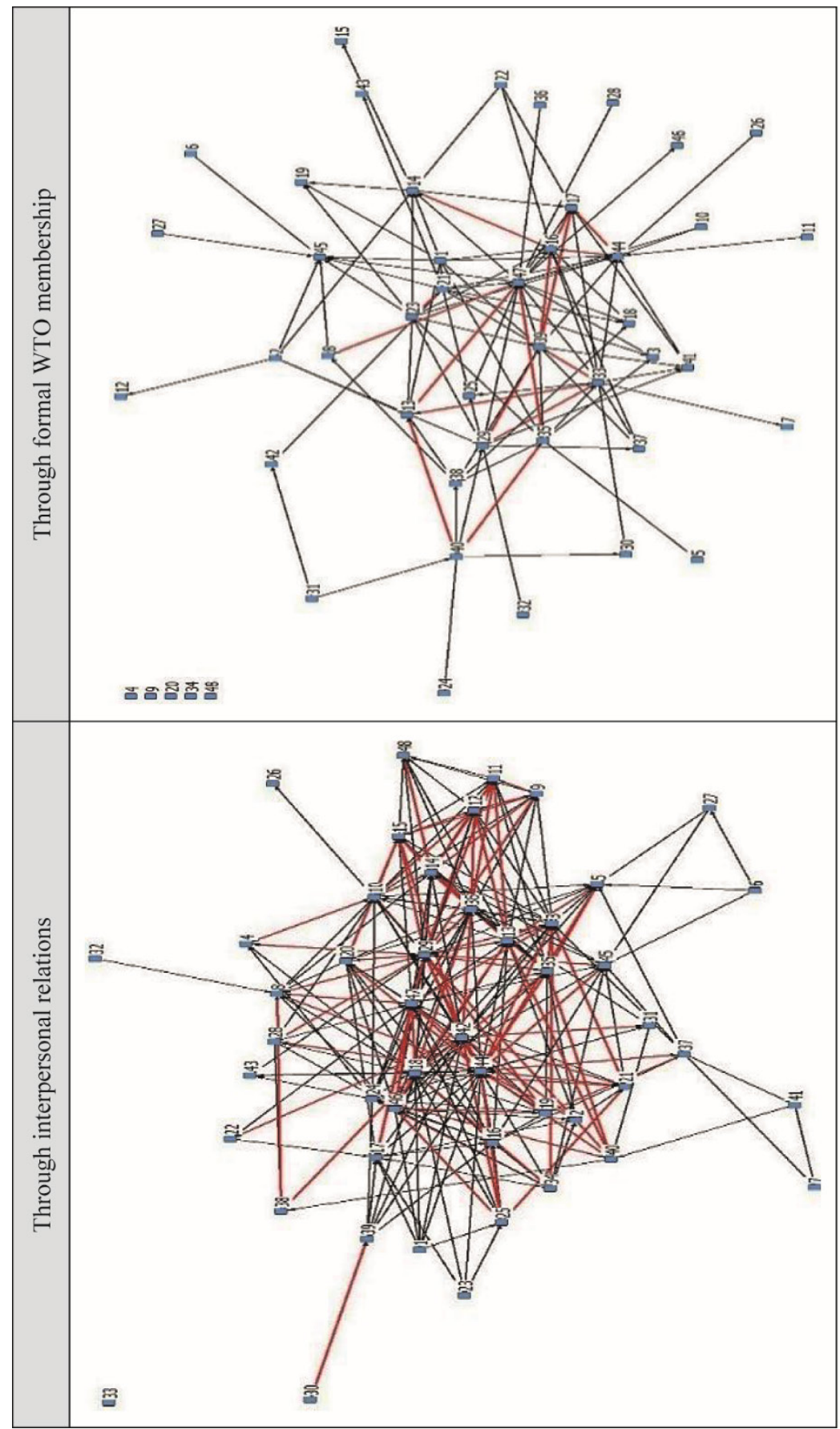

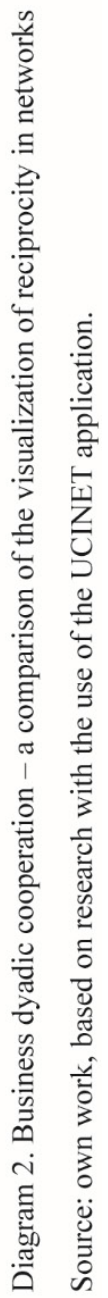


medium distance between nodes). This translates into the general connectedness in this network amounting to 0.821 , while in the case of cooperation formed through formal membership in the WTO-to only 0.338. This made the level of separation of actors in the first type of network much lower than in the second (fragmentation 0.179 versus 0.662 ).

Table 5

Characteristics of cooperation established through formal WTO membership or through interpersonal relations with the use of chosen network cohesion measures

\begin{tabular}{l|c|c}
\hline \multicolumn{1}{c|}{ Parameter } & $\begin{array}{c}\text { Cooperation established } \\
\text { through WTO membership }\end{array}$ & $\begin{array}{c}\text { Cooperation established } \\
\text { through interpersonal relations }\end{array}$ \\
\hline Components & 33 & 9 \\
\hline Degree centralization & 0.231 & 0.460 \\
\hline Diameter & 7 & 6 \\
\hline Average distance & 2.723 & 2.198 \\
\hline Connectedness & 0.338 & 0.821 \\
\hline Fragmentation & 0.662 & 0.179 \\
\hline
\end{tabular}

Source: own work, based on research, with the use of the UCINET application.

It was not only quantitative SNA which supported the claim that in Wisła social relationships were more important than formal ones in running a business, including establishing dyadic business cooperation. Some interviewees also stated that private contacts are much more important than formal membership in any organization, including the WTO:

Researcher: "So you mean that these private relationships, often even from school...".

Interviewee: "They are more useful, more helpful, in quotes - inbusiness

- than any membership in any organization" [Interviewee no. 6].

"I will tell you that at the beginning of the establishment of the 'Wista Tourist Organization', I thought that we [our business] would be more visible, but in fact, after a couple of years, I found that the contacts that were established before were the most important" [Interviewee no. 42].

It should be emphasized, however, that membership in formal organizations like the WTO could be used to build such personal, informal relationships. An example of two actors (nos. 13 and 35) presented later in the paper, shows that if entrepreneurs were motivated enough they could use membership in the WTO to build such social relationships. 


\subsection{Analysis from the perspective of actors in the network}

To present the role of social embeddedness, the authors also apply the analysis from the point of view of particular actors (the second step of analysis - see Scheme 3). The quantitative SNA enabled identification of central and peripheral actors - the most and the least active in business cooperation.

To identify such actors, different centrality parameters were used degree, betweenness and closeness (mentioned in section 2.3, Table 2). However, indegree and outdegree centrality were chosen as the most important, showing how many business partners a particular actor has. The analysis of the network reflecting business cooperation between WTO members enabled identification of the top nine central actors (marked in red in Diagram 3) and also the nine most peripheral ones (highlighted in green in Diagram 3, and also presented in Table 6 on a lighter background) (the full list of actors and their centrality parameters are presented in the Appendix $)^{2}$.

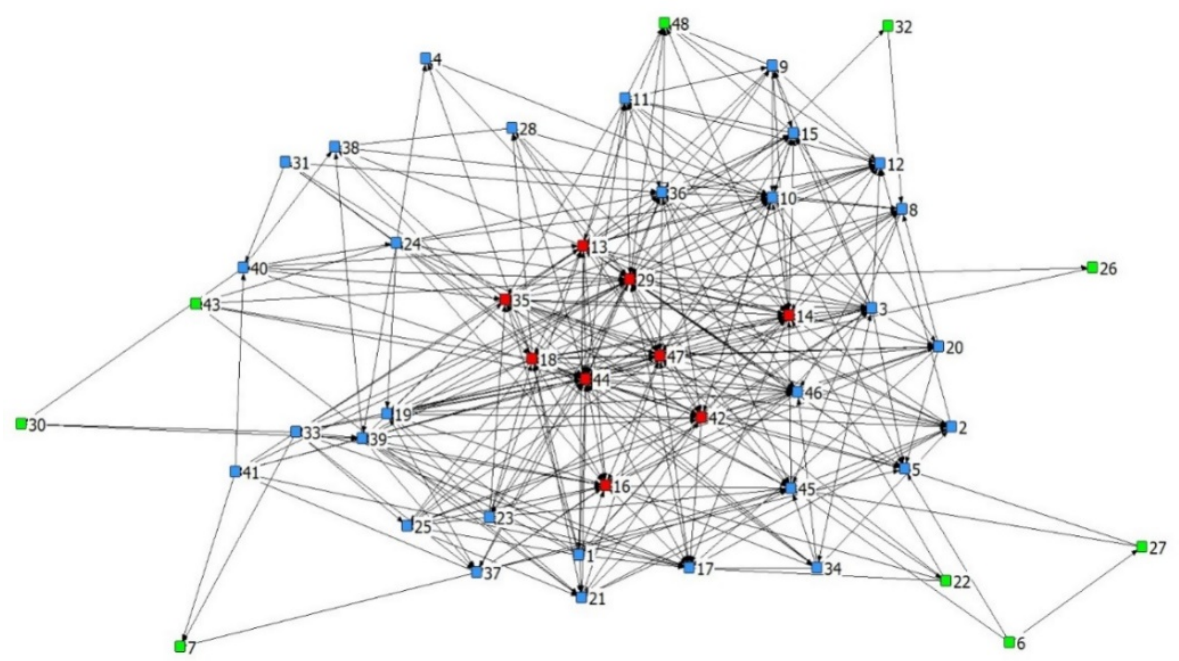

Diagram 3. Central and peripheral actors in the network of business cooperation

Source: own elaboration based on research.

\footnotetext{
${ }^{2}$ The highest outdegree centrality was 35 , so those with outdegree centrality of 18 and more were chosen as central actors (more than half of the top centrality actors). The highest indegree centrality was 32 , so those of indegree centrality 16 and more were chosen as central actors. Those with 0 or 1 indegree, and also $0-1$ outdegree were chosen as peripheral actors.
} 
Table 6

Central and peripheral actors according to different centrality measures

\begin{tabular}{|c|c|c|c|c|c|c|}
\hline $\begin{array}{c}\text { Type } \\
\text { of actor }\end{array}$ & No. & Out-degree & In-degree & Out closeness & In closeness & Betweenness \\
\hline \multirow{9}{*}{ 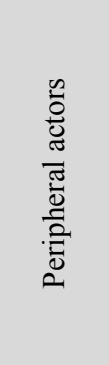 } & 7 & 0 & 3 & 235 & 135 & 0.000 \\
\hline & 43 & 0 & 5 & 235 & 98 & 0.000 \\
\hline & 26 & 1 & 1 & 121 & 120 & 0.000 \\
\hline & 30 & 1 & 3 & 137 & 129 & 0.250 \\
\hline & 32 & 1 & 1 & 142 & 120 & 0.000 \\
\hline & 48 & 1 & 8 & 140 & 104 & 0.000 \\
\hline & 6 & 3 & 0 & 135 & 235 & 0.000 \\
\hline & 22 & 5 & 1 & 110 & 136 & 0.111 \\
\hline & 27 & 2 & 1 & 139 & 231 & 0.000 \\
\hline \multirow{9}{*}{ 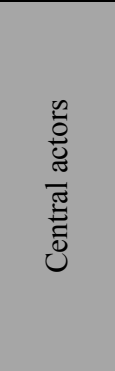 } & 29 & 35 & 24 & 65 & 77 & 475.878 \\
\hline & 44 & 22 & 32 & 78 & 69 & 369.300 \\
\hline & 18 & 21 & 14 & 82 & 92 & 126.801 \\
\hline & 13 & 20 & 17 & 82 & 87 & 97.154 \\
\hline & 42 & 18 & 13 & 84 & 92 & 148.837 \\
\hline & 47 & 15 & 21 & 90 & 82 & 66.214 \\
\hline & 14 & 14 & 19 & 96 & 85 & 108.667 \\
\hline & 16 & 6 & 19 & 99 & 83 & 32.676 \\
\hline & 35 & 13 & 16 & 89 & 85 & 61.623 \\
\hline
\end{tabular}

Source: own, elaboration based on research.

The answers to the open-ended questions used during the interview showed that there were a few reasons why individual actors were peripheral in the network. In some cases (e.g. actor 48), the cause was the large geographical distance from other partners, hindering business cooperation. In the case of actor 43, the peripheral position was a result of the fact that the owner had a few related businesses in Wisła and his different types of companies (hotel, restaurant, etc.) cooperated mainly with each other. Interviewee no. 32 pointed to more personal reasons such as approaching retirement age and the lack of strength and willingness to cooperate with other entrepreneurs. Another entrepreneur, actor no 22, referred to the specificity of her facility (a holiday camp centre for Seventh-Day Adventist church tourist groups with specific and very strict rules in the accommodation facility which, to some extent, made it difficult to find a partner, e.g. recommend other accommodation to a very unique segment of tourists).

However, five out of nine peripheral actors (actors nos. 7, 26, 30, 6 and 27) admitted that their withdrawn attitude towards dyadic business 


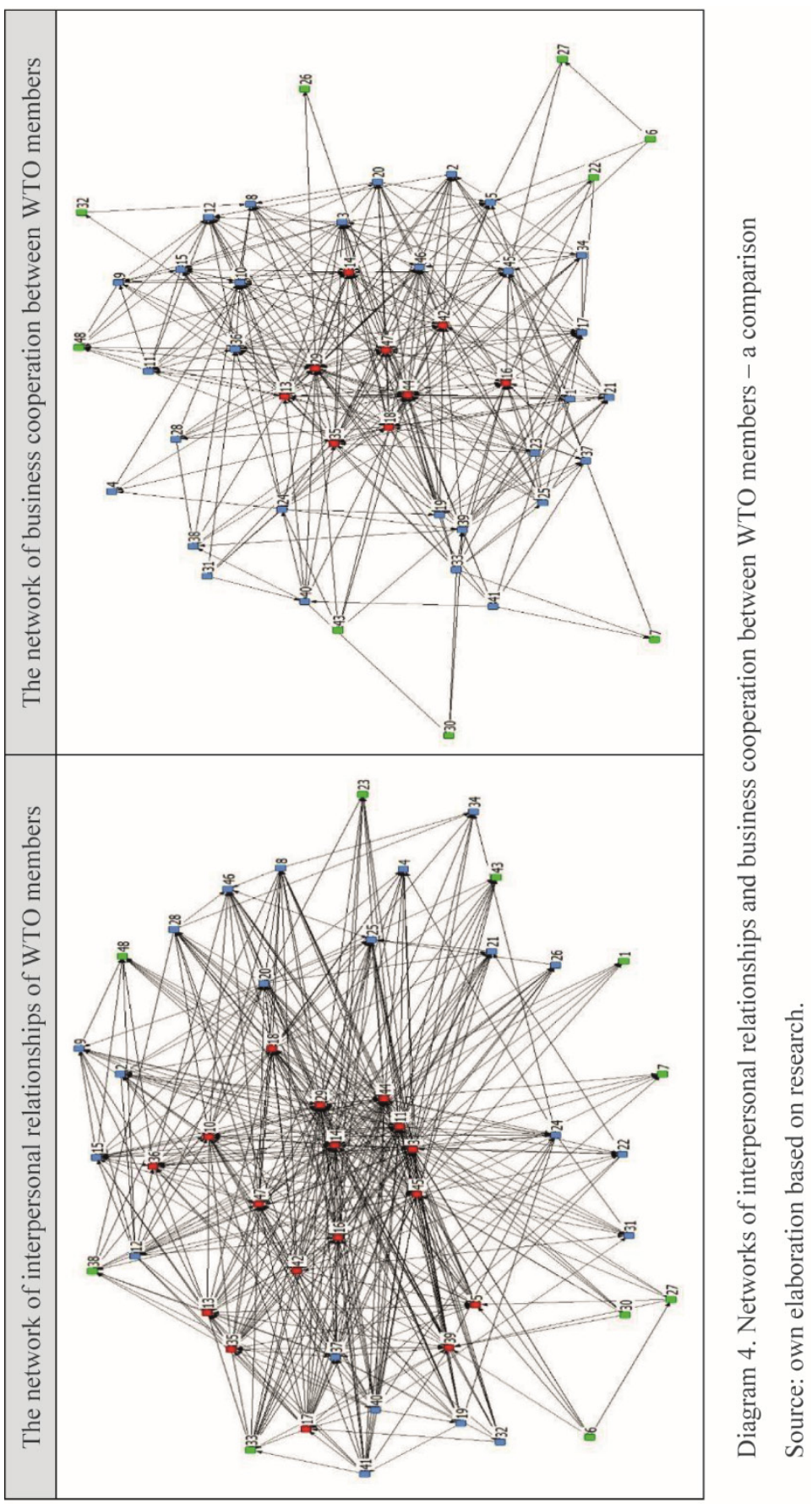


cooperation was directly due to the fact that they were not socially embedded in the local community. Four of them were also in a group of 13 actors who, to one of questions asked by the researcher, pointed to the smallest number of actors with whom they maintain interpersonal relationships - see Table 6. Diagram 4 shows that peripheral actors in business cooperation are those who are usually also peripheral in the network of actors' interpersonal relationships.

All five peripheral actors in business cooperation who were not socially embedded in the local community(nos. 7, 26, 30, 6 and 27),came from outside Wisła. In addition, two out of five companies were located on the borders of Wisła and a nearby municipality called Istebna (administratively they were located in the second). The actors representing them - nos. 6 and 27 - declared cooperation with up to 3 out of 47 entities. According to the interviewees, the fact that their business was located in Istebna caused, firstly, that they did not feel embedded in the Wisła community (although they knew some entrepreneurs from that municipality), and secondly, the physical distance further hindered economic cooperation with other entities:

"I do not cooperate with anyone. Just with the WTO as an organization. I think they are all down there, because if someone [a guest] is going to do a party, then he has to come back here [up to the interviewee's restaurant in Istebna] again, you know. It is also hard to get here (...). The WTO is more focused on cities like Wista and Ustron [close to Wista], and they [WTO representatives] came here [with an invitation to join the WTO] because I know these people - basically one or two people" [Interviewee no. 6].

On the other hand, actors 7, 26 and 30 ran their businesses in the centre of Wisła, but claimed that they were not active entities in business cooperation because they did not come from Wisła, did not know the local community and therefore felt like outsiders. Interviewee no. 7 was the owner of a restaurant, while entrepreneurs nos. 26 and 30 ran guesthouses in Wisła. In addition, interviewee no. 26 stated that she lives in Cieszyn (about $90 \mathrm{~km}$ from Wisła) and the lack of time hinders her ability to get to know the local community and establish interpersonal relationships within it:

Researcher: "Well, do you have any such direct, interpersonal relationships with any of these WTO entities?",

Interviewee: "No, when a person is not from Wista... I don't even know them at all (...). There is just no time to meet or anything, because in the evening I get in the car and go to Cieszyn". 
Researcher: "So, what about people from the WTO - do you know anyone?".

Interviewee: "No, no, that is, from the board, yes, yes, and the treasurer ... we can tick them [in the survey]" [Interviewee no. 26].

However, interviewee no. 30 (who indicated that she cooperates with only one WTO member and was mentioned only by three of them) described her situation as follows:

Researcher: "Do you feel that you are from the outside?".

Interviewee: "We still feel the difference because no one is trying, no one will call us, for example, whether we have free places (...). And to this day I don't believe it, because they are in the centre, for sure they have their fixed guests, surely they have periods where they have full occupancy and they have emails and phone numbers anyway, and it was never like: 'maybe there, maybe go to ...' [the name of a guesthouse represented by the interlocutor]. No, there is no such a recommendation at all (...) Well, I don't contact elsewhere because nobody cares about me, especially taking into account that I'm not from here. I think we would all be better if they were looking after me. At this moment I have a group and I have occupied rooms so I cannot take any further guests and I have questions about the possibility of booking a room in another place, so I could send them back [to other guesthouses], but I don't" [Interviewee no. 30].

Aside from the peripheral actors, nine actors (numbers: 29, 44, 18,13, 42, $47,14,16,35)$ were identified as occupying the most central position in the network of business cooperation. All of them had the highest level of degree centrality and they were also central actors regarding two other centrality measures - closeness and betweenness - see Table 2 in the Appendix. For example, actor 29 pointed to nearly $75 \%$ of WTO members as his business cooperators (outdegree $=35$ ), and at the same time was mentioned as a business partner by nearly $51 \%$ of them. In addition, all the nine actors indicated the largest number of entities with whom they maintained personal relationships - here they even listed $100 \%$ of the WTO entities.

Qualitative analysis made it possible to identify the reasons for occupying a central position in the network of business dyadic cooperation. Unlike explaining actors' peripheral position, which in most cases unambiguously stemmed from specific, individual characteristics described by the interviewees (geographical distance, age of entrepreneur, retirement, etc.), in this case, according to interlocutors' declarations, the fact that they occupied 
a central position in the network of business cooperation stemmed from several reasons simultaneously, with social embeddedness as one of them.

Some of the respondents (actors: 42, 44, 47 and 29) represented economic operators providing highly complementary goods and services to other WTO members (transport, IT, events). This made these entities desirable partners for cooperation - they were often mentioned as partners by other interviewees (high indegree centrality) or they mentioned multiple actors as their partners (high outdegree centrality). This group of actors also included a member of the Wisła local authorities (actor no. 47), maintaining numerous interpersonal relationships with tourism entrepreneurs due to municipal office statutory duties.

However, crucially, all the central actors were characterized as socially embedded in the local community (structural embeddedness) and strongly stressed that this feature had a significant influence on their active role in business cooperation with other entrepreneurs in Wisła. Seven of them declared that they originally came from Wisła and knew personally most of the WTO members before the organization was established. As they declared, this made it easier to start business dyadic cooperation with those actors. The owner of a guesthouse in Wisła confirmed the role of social embeddedness in business cooperation with these words:

Researcher: "Is it important [Wista origin] in Wista and can it be important for business cooperation?".

Interviewee: "It may be important, because these people for sure know each other better. It is difficult for sure for those who come [from the outside] because they have to break in a bit" [Interviewee no. 36].

Moreover, by occupying a central position in the network of WTO members, the actors could play a variety of roles, particularly leadership roles, which could generate multiple benefits for the network and its members. As further analysis showed, seven out of the nine central actors in business cooperation (no. 14, 44, 29, 47, 16, 13 and 35) were members of the WTO board and played the network broker (according to betweenness centrality), gatekeeper and coordinator roles (according to degree and closeness centrality) - see Table 6. Importantly, all these actors were the initiators of creating the WTO in 2008. They encouraged other entrepreneurs with whom they sustained interpersonal contacts to join the WTO:

Researcher: "How did you become a member of the WTO? Did you get any official invitation, for example from the local authorities?". 
Interviewee: "You know what? No! Wista is a small town and everybody knows one another, so I was simply invited to join the WTO”.

Researcher: "So, via social channels, i.e. someone among your friends told you?".

Interviewee: "Exactly. It was Andrzej [actor 29] who came here and encouraged me to join it" [Interviewee no. 3 ].

Interestingly, most of the interviewees -42 out of 48 - claimed that they became WTO members thanks to information they received from other entrepreneurs with whom they maintained interpersonal relationships. This confirms the role of social embeddedness as a trigger of network cooperation.

Moreover, the interest of those seven socially embedded, central actors in WTO activities and their selection to the board by other WTO members was influenced by, among other things, the high level of their embeddedness in the local community. People voted for them because they were known in the local community. As people embedded in the local community, they were also strongly engaged in developing tourism in Wisła, which translated into performing different functions (e.g. being on the WTO board). One of the WTO board members described his attitude to tourism development in Wisła in this way:

Interviewee: "And I will try to help in other fields, to support tourism in Wista, not only because we have two companies that live from this [tourism] (...). And we are interested, but as I say, it's not just that. Since 1800, my family has been very active here and has worked and farmed and have become doctors and teachers in this area".

Researcher: "You are from Wista, aren't you?".

Interviewee: "Yes, and this idealistic approach is very important to us in my family, and it is more difficult for us to give up [membership in the WTO] than for others, right?" [Interviewee 29].

At the same time, the interviewees claimed that thanks to the membership in the WTO board they had better knowledge about other entrepreneurs in Wisła and this had an effect on their businesses. One of the entrepreneurs, a guesthouse owner, who was employed in the WTO described it as follows:

Researcher: "With which WTO members do you have better information flow due to affiliation with the WTO?". 
Interviewee: "With all the board. But you see, if I didn't work on the WTO board it would be different (...). Because now it is possible to get to know them, because now I personally have better knowledge as a WTO employee" [Interviewee 39].

The WTO leadership role of the central actors (who were embedded in the network of social relationships) was also confirmed when the interviewees were asked to nominate actors who according to them were leaders in the WTO (but not necessarily formal ones - the aim was to identify actors who were the most engaged in WTO cooperation). Out of the nine central actors in the network of business cooperation, six nodes (nos. 14, 44, 29, 47, 16 and 35) were most often referred to as such leaders (by 11 to 22 entities). In addition, each of them also identified themselves as a leader or at least one of the leaders in the organization.

Moreover, central actors (including those whose central position in the network resulted - as they declared - from their social embeddedness in the local community) could, due to their predispositions, be perceived as desirable/attractive partners for future cooperation. This was also confirmed by empirical research. In one of the questions the respondents were asked to identify the most desirable business partners - from the point of view of the needs of a given entrepreneur. As many as seven out of nine central entities, which were strongly embedded in the local community (nos. 14, 44, 29, 18, $47,16,13)$,were most often cited as desirable partners for cooperation. Some of them - for instance actor 44 -were undoubtedly mentioned because of their attractive business product offer. However, when interviewees were asked why they chose this actor instead of a competitor, they often claimed that the person is known in the local community, has a good reputation and that was a deciding factor in their final choice. Some interviewees - e.g. the manager of a big, popular hotel in Wisła - claimed that thanks to joint membership in the WTO she was able to get to know a partner better (actor 44) and his reputation in the local community, and this stimulated dyadic business cooperation with him:

"The WTO certainly somehow made [this cooperation] possible because we got to know each other in the WTO very well, and basically such close cooperation with Marcin has started since we were in the WTO (...). [After some time] began claims [from Marcin's competitors] that Marcin has some kind of exclusivity with us. He has no exclusivity with us, but he is the most organized in cooperation. We cooperate 
very well (...). We work with Marcin, but this is not the only company, because there is also [name of a company] in Wista, with which we could cooperate, but Marcin has earned the trust we gave him" [Interviewee 16].

Out of the eight actors who indicated the highest number of WTO members as desired future partners (declaring their willingness to cooperate even with all of them), six were those who were strongly socially embedded in the local community and at the same time were the most engaged in business cooperation in Wisła. This is presented in more detail in Table 8.

The opposite situation could be seen in the case of peripheral actors who were not engaged in cooperation due to the lack of social embeddedness in the local community. All five such actors (nos. 7, 26, 30, 27, 6) pointed out the lowest number of desirable future partners to cooperate with (they did not mention anyone or two entities at most), and four out of the five were least frequently indicated by other partners as desired partners for cooperation (maximum by four entities) - see further details in Table 9.

As further analysis showed, in each of these five cases, the reason was a low level of knowledge about other partners - about the kind of businesses they ran and how potential cooperation with them could be useful:

Interviewee: "I do not know anyone at all, I do not answer, because no-one..."

Researcher: "So, when it comes to people in the WTO, do you know anyone?".

Interviewee: "No, no ... I mean, the board leader, yes, and the treasurer ...".

Researcher: "So should I tick these two people?".

Interviewee: "These guys only - I have been in a contact with them, but the rest, no" [Interviewee no. 7].

It can be assumed that for outsiders, membership in such formal organizations as the WTO could be very significant. In one venue (for example, during a general meeting of members), many entrepreneurs are present and this is a great opportunity to get acquainted and in the future to establish business cooperation. Considering these potential benefits and assuming that entrepreneurs were aware of them and willing to use them, quantitative SNA of the network of business cooperation established through joint WTO 
membership, should indicate as central entities (e.g. those declaring the highest number of cooperative relationships with others) primarily those actors who were not embedded in the local community. This would mean that they are taking advantage of the fact that they are a WTO member in order to establish business dyadic cooperation with previously unknown entities.

What is interesting, however, is that it turned out that in the network of cooperation based on joint formal WTO membership, 10 out of 13 of the most central actors (taking into account the indegree and outdegree parameters) were socially embedded in the local community and had known each other long before becoming WTO members. Only 3 of these 13 entities were not socially embedded in the local community when they decided to join the WTO. This implies that although for people embedded in the local community WTO affiliation should not play a key role in establishing individual business cooperation (they were already known to most WTO members),this formal membership was used to deepen their contacts with other WTO members (see Table 7).

Table 7

Central actors according to different centrality measures in the network of business cooperation established through joint formal membership in the WTO

\begin{tabular}{c|c|c|c|c|c}
\hline Actor number & Out-degree & In-degree & Out-closeness & In-closeness & Betweenness \\
\hline 47 & 13 & 9 & 376 & 232 & 229.413 \\
\hline 33 & 12 & 4 & 193 & 243 & 69.750 \\
\hline 21 & 10 & 2 & 194 & 276 & 53.629 \\
\hline 39 & 10 & 7 & 194 & 234 & 204.813 \\
\hline 1 & 9 & 0 & 187 & 376 & 0.000 \\
\hline 23 & 9 & 2 & 193 & 255 & 82.646 \\
\hline 29 & 7 & 5 & 200 & 236 & 149.281 \\
\hline 44 & 2 & 12 & 240 & 225 & 65.050 \\
\hline 16 & 6 & 9 & 212 & 227 & 98.787 \\
\hline 17 & 3 & 8 & 217 & 228 & 85.858 \\
\hline 45 & 0 & 8 & 376 & 225 & 0.000 \\
\hline 13 & 4 & 6 & 205 & 243 & 42.964 \\
\hline 14 & 4 & 6 & 236 & 233 & 44.417 \\
\hline
\end{tabular}

*As outdegree central actors the researcher considered those with an outdegree parameter of 7 or more (maximum 13) and as indegree central actors those with an indegree parameter of 6 or more (maximum 12).

Source: own work based on research. 
At the same time, this showed that entrepreneurs who were not embedded in the local community did not exploit the wide range of opportunities offered by membership in the WTO. This was confirmed by the words of the owner of a transport company, a person who was strongly embedded in the local community:

Interviewee: "You, know, in order to achieve this aim, firstly, to start consolidating all those people who were here for some life reason, one or another, I proposed to the Wista Tourist Organization, a Christmas meeting. It was supposed to be based on showing to outside people that these traditions here are based on some other phenomena, than what they [outside people] are accustomed to. And besides, this cuisine is different too (...) So, you know, to this particular Christmas meeting came all in all more local people, that means those who run this kind of business than, for example, actually those from the outside - for whom it was mainly organized and proposed (...). They treated this topic without any involvement, although, as I say, the first idea was to show these people, these people in particular, a little bit of the highlander culture so they could cultivate it at home [their accommodation businesses]. And to put it gently... they ignored the topic "[Interviewee no. 42].

Some exceptions of actors who used WTO membership to become socially embedded in the local community were actors nos. 13 and 14, who run an agritourism business and a guesthouse. Many interviewees stressed that they were a great example of entrepreneurs who at the beginning were not embedded in the local community (they came to the municipality a few years before the research was conducted), but their membership in the WTO allowed other entrepreneurs to meet them and to appreciate their engagement in local tourism development. This translated into their popularity as business partners in dyadic cooperation:

"There are some people who have started something new here, however they just wanted to do something with us. And in general [the name of actor 13] or someone else like that are people who came here a couple of years ago and I think they feel very good with us. Because they want to [Interviewee 36].

To conclude, after conducting qualitative and quantitative analysis, it can be stated that social embeddedness may foster cooperation, as the following findings show. All the top nine central actors in the network of business cooperation explained that their strong engagement in cooperation with other 
actors was in part due to the fact that they were socially embedded in the local environment. Moreover (see Table 8):

- all the top 9 central actors had the highest number of interpersonal relationships with other network actors (some claimed to have relationships with all or almost all WTO members);

- 7out of 9 actors were frequently cited as desirable partners in business cooperation;

- 6 out of 9 mentioned the highest number of network actors (even all WTO members) with whom they would like to form a cooperative relationship;

- 6 out of 9 actors were perceived mostly as WTO leaders;

- 7 out of 9 were on the WTO board at the time when the research was conducted or had been in the past, so they had a real impact on tourism cooperation in Wisła and on what was going on in the development of tourism in the municipality.

Table 8

Selected features of socially embedded central actors in business cooperation

\begin{tabular}{l|c|c|c|c|c|c|c|c|c}
\hline \multicolumn{1}{c}{$\begin{array}{c}\text { Central actors in business cooperation due } \\
\text { to their social embeddedness }\end{array}$} & 14 & 44 & 29 & 18 & 42 & 47 & 16 & 13 & 35 \\
\hline $\begin{array}{l}\text { Actors with the highest number of interpersonal } \\
\text { relations }\end{array}$ & $\mathrm{X}$ & $\mathrm{X}$ & $\mathrm{X}$ & $\mathrm{X}$ & $\mathrm{X}$ & $\mathrm{X}$ & $\mathrm{X}$ & $\mathrm{X}$ & $\mathrm{X}$ \\
\hline Actors who were members of the WTO board & $\mathrm{X}$ & $\mathrm{X}$ & $\mathrm{X}$ & & & $\mathrm{X}$ & $\mathrm{X}$ & $\mathrm{X}$ & $\mathrm{X}$ \\
\hline Actors perceived as leaders in the WTO & $\mathrm{X}$ & $\mathrm{X}$ & $\mathrm{X}$ & & & $\mathrm{X}$ & $\mathrm{X}$ & & $\mathrm{X}$ \\
\hline $\begin{array}{l}\text { Actors mentioning the highest number of desirable } \\
\text { potential business partners (from 15 to 47) }\end{array}$ & & $\mathrm{X}$ & $\mathrm{X}$ & $\mathrm{X}$ & $\mathrm{X}$ & $\mathrm{X}$ & & $\mathrm{X}$ & \\
\hline $\begin{array}{l}\text { Actors mentioned most often as desirable } \\
\text { potential business partners (by16 to 28 entities) }\end{array}$ & $\mathrm{X}$ & $\mathrm{X}$ & $\mathrm{X}$ & $\mathrm{X}$ & & $\mathrm{X}$ & $\mathrm{X}$ & $\mathrm{X}$ & \\
\hline
\end{tabular}

Source: own work based on research.

Table 9

Selected features of socially embedded peripheral actors in business cooperation

\begin{tabular}{l|c|c|c|c|c}
\hline \multicolumn{1}{c|}{$\begin{array}{c}\text { Peripheral actors in business cooperation due to their lack } \\
\text { of social embeddedness }\end{array}$} & 7 & 26 & 30 & 6 & 27 \\
\hline $\begin{array}{l}\text { Actors with the lowest number of interpersonal relations } \\
\text { The lack of any function in the WTO }\end{array}$ & $\mathrm{X}$ & & $\mathrm{X}$ & $\mathrm{X}$ & $\mathrm{X}$ \\
\hline $\begin{array}{l}\text { Actors mentioning the lowest number of desirable potential partners } \\
\text { (up to 2 partners) }\end{array}$ & $\mathrm{X}$ & $\mathrm{X}$ & $\mathrm{X}$ & $\mathrm{X}$ \\
\hline $\begin{array}{l}\text { Actors mentioned the least as desirable potential partners (by 2 to 4 } \\
\text { entities) }\end{array}$ & $\mathrm{X}$ & $\mathrm{X}$ & $\mathrm{X}$ & & \\
\hline
\end{tabular}

Source: own work based on research. 
At the same time, quantitative and qualitative analysis of the SNA showed that out of the nine top peripheral actors in the network of business cooperation, five explained that their lack of cooperation engagement was directly due to the fact that they were not socially embedded in the local community. Moreover (see Table 9):

- 4 out of those 5 actors had the lowest number of personal relationships with other actors in the network;

- all of these 5 actors were mentioned least often as desirable partners in cooperation (by up to 4 entities);

- 3 out of 5 of those actors mentioned the lowest number of other entities in the network with whom they would like to establish a cooperative relationship;

- none of those peripheral actors played any role in the WTO either in the past or at the time the research was conducted, so they had no real impact on cooperation in Wisła and on what was going on in the development of tourism in the municipality.

\section{DISCUSSION}

The research showed that, similarly to other sectors of the economy, in the tourism sector the actors' embeddedness in social relationships also influences economic activities, in this case - business collaboration with other enterprises (Jack, 2005; Powell, 1990; Uzzi, 1999). The research showed that social embeddedness triggered business dyadic cooperation - it helped actors to start such cooperation. More business partners were found through interpersonal relationships than through formal membership of the WTO, even though this was one of the most important reasons for establishing the organization. Socially embedded actors also initiated the establishment of the WTO and encouraged other entrepreneurs to join the organization. The majority of WTO members received information about the possibility of becoming WTO members from entities with whom they had informal relationships. This is in line with Beritelli's (2011) research results which claimed that a personal liking between partners is very important, and when examining an individual entity, one should also take into consideration the context (that is the structure of relations) in which this entity functions (Beritelli, 2011).

Moreover, by comparing the cohesion (analysed by density, reciprocity of relations, diameter, etc.) of both types of networks - the first based on informal relationships and the second based on formal membership of the 
WTO - it could be stated that in the researched community, networks built through interpersonal relations were more coherent and potentially more effective. Thanks to a higher density of relationships, higher level of reciprocity of relations, shorter distance to other entities in the network, smaller number of network components etc., in such networks resources could flow easier, faster and with a lower transaction cost. This is in line with statements by authors who claim that social embeddedness provides access to important and value resources (e.g. knowledge, capital, etc.) (Andersen, 2013; Chell and Baines, 2000), raises the flexibility of problemsolving by using reduced resources (Larson, 1992; Lechner, Dowling, 2003; Poppo, Zenger, 2002; Uzzi 1996; Zukin and DiMaggio, 1990), makes transaction costs lower (Baum, Oliver, 1992; Domhoff, 1971; Granovetter, 1985; Peng, Lee and Wang, 2005; Rutashobya, Jaensson, 2004; Useem, 1979), and allows for a more precise transfer of information (Davidsson, Hoing, 2003; Ellis, 2011; Granovetter, 1985; Uzzi, 1997).

However, it must be stressed that overly cohesive networks, especially those with too high a density of relations, could be ineffective. Too much cohesion implies that the actors might be closed to outside partners and thus are not innovative, proactive or able to make optimal economic decisions. Although it was not the aim of this paper, the research also revealed some disadvantages of actors' social embeddedness such as:lower innovativeness of cooperative activities, reduced flexibility of partners and the partnership organization to external changes, interpersonal conflicts or greater susceptibility to partner's opportunistic actions, etc. This supports the existing results of research on the'dark sides' of embeddedness in different branches of the economy other than tourism (see e.g. Burt, 1992; Gargiulo and Benassi 2000; Granovetter, 2005; Håkansson, Snehota, 1998; Mitręga and Żółkiewski, 2012; Mizruchi, Stearns, 2001; Nahapiet, Ghoshal, 1998; Portes, Sensenbrenner 1998; Uzzi 1997).

Moreover, the quantitative part of the research allowed to identify the peripheral and central actors in the network of business cooperation. More than half of the interviewees identified as the most peripheral actors (the least engaged in business dyadic cooperation) admitted that their withdrawn attitude towards such cooperation was directly due to the fact that they were not socially embedded in the local community. At the same time, all the top central actors were socially embedded in the local community and mentioned this embeddedness as one of the most important reasons why they were such active business partners in Wisła. Additionally, the majority of the actors who were the most active in business cooperation were members of 
the WTO board, and were perceived as undisputed leaders of this organization by other WTO members. As they claimed, their selection to the WTO board was influenced by, among other things, the high level of their social embeddedness in the local community. They also stressed that they decided to perform functions in the WTO because they were truly interested in tourism development in Wisła, and claimed that, thanks to the fact they were in the WTO board, they were more recognizable in the local community, which may have affected their popularity as business partners. This is in line with other research emphasizing that entities socially embedded in the local community are more inclined to engage in activities serving the local community - e.g. non-profit organizations, charities, etc. (Czernek, 2014; Jack and Anderson, 2002; Jack et al. 2008). The situation was reversed in the case of the most peripheral actors who were not socially embedded in the local community.

Last but not least, the interviewees often claimed that with some partners they maintained both types of relationship. In some situations, the interviewees even had difficulty in clearly indicating the source of a given relationship. They underlined the multidimensionality of relations - their simultaneous business and personal context. Thus, one might assume that formal and informal relationships are mixed, they affect each other and there is constant feedback between them. This is in line with statements presented by Granovetter (1985, 2005), Uzzi (1999), Jack, Dodd and Anderson (2008) and other authors regarding other sectors of economy. In addition, the results of the study confirm the conclusions of Granovetter's works (1990; 2005), that not only social relationships affect business relationships, but also business relationships enable partners to build closer personal relationships. It was not uncommon for the interviewed entrepreneurs to first establish business market transactions, which over some time provided an opportunity for partners to become better acquainted, to develop mutual trust, personal closeness, and to have a sense of reciprocity, thereby transforming market relationships into social ones.

\section{CONCLUSIONS}

The aim of the paper was achieved. The research confirmed the role of social embeddedness as a trigger for cooperation in a tourist region. Additionally, it also allowed for the formulation of some general conclusions of a methodological and practical character, as well as pointing to some research limitations and future research recommendations that have to be emphasised. 
Regarding methodological issues, the research revealed that combining quantitative SNA and qualitative analysis of social embeddedness allows for a better explanation of its role in collaboration. This supports the views mentioned in the second part of the paper on the legitimacy of using both types of approach. The research allowed to show how they can be used and what kind of benefits they generate. It confirmed that mixed methods can provide a specific contribution to investigating social networks in the form of a detailed description of a network, network practices and interpretation, and network effects. The research showed that combining both methods allows for a better understanding of how individuals position themselves in relation to their social context and what are the patterns of actors' contacts regarding business cooperation. It also allowed for a better understanding of the role of social embeddedness in producing certain network outcomes, e.g. business cooperation.

Regarding practical conclusions, one may argue that - taking into consideration that the collaboration process brings positive results for the actors involved, and, in a broader perspective, for the whole tourist destination - it is crucial to maintain personal relationships between actors who directly and indirectly develop tourist activity in a given destination. Personal and business links are here strictly interconnected, and there is a large amount of feedback between them. Such feedback may create positive effects and facilitate collaboration, or, when formed incorrectly, hamper it. Thus, personal relationships should be perceived as a specific economic asset and a necessary condition of future, measurable economic benefits. All research on social capital proves the economic potential of personal relationships.

There are, however, some limitations to the research presented. Firstly, the research describes a very specific context of relations in one Polish municipality - Wisła. Thus, the results of the paper cannot be treated as representative for destinations in other countries or even in some other places located in Poland. Secondly, the research presents the WTO as a network of 48 members, although at the time when the research was conducted, the organization numbered 55 members (seven did not agree to take part in the research). Although according to their own statements and those of WTO representatives, they were completely inactive members, their presence in the research could to some extent have changed the research results obtained (especially the calculated parameters such as density, number of peripheral actors or reasons for occupying such a position). However, thanks to combining qualitative and quantitative analyses in the paper, it can be stated that excluding those actors from the network would 
not have altered the final conclusions about the very important role of interpersonal contacts in dyadic and network cooperation. Another important limitation is that the research does not allow us to identify and measure the strength of social embeddedness and its unambiguous influence on business cooperation. This factor was only one of a few interlinked determinants of such cooperation mentioned by interviewees. Additionally, in each case and in each different situation its role was perceived differently. Yet the research showed clearly that embeddedness is an important, sometimes even crucial factor in business cooperation, and cannot be underestimated in further empirical research.

Regarding the implications for future research, analyses of the role of social embeddedness in cooperation in other municipalities in Poland and other countries are highly recommended. As presented in this paper, the social context influencing a network structure and actors' decisions is very specific in different areas - thus, its impact in other locations could be completely different. For example, social embeddedness would affect business cooperation differently in small villages such as Wisła, than in big cities covering a much larger area. Moreover the role of social embeddedness in business cooperation should also be analysed with regard to other aspects of economic activity in the tourism sector, for example, starting new businesses and developing existing businesses, finding investors for small and big investments etc. It is certain that the social embeddedness of tourist entrepreneurs affects the decisions and actions they have to face in their day to day business activity. The topic is therefore worth further empirical investigation.

\section{REFERENCES}

Arrow, K. J., Observations in social capital, [in:] Dagsupta, P., Serageldin, I. (eds.), Social Capital: A Multifaceted Perspective. International Bank for Reconstruction and Development/ The World Bank, Washington, DC, 2000.

Baggio, R., Collaboration and cooperation in a tourism destination: a network science approach, "Current Issues in Tourism", Vol. 14(2), pp. 183-189, 2011.

Baggio, R., Network science and tourism-the state of the art, "Tourism Review" Vol. 72 (1), pp. 120-131, 2017.

Baggio, R., Del Chiappa, G., Real and virtual relationships in tourism digital ecosystems, "Information Technology \& Tourism", Vol. 14(1), pp. 3-19, 2014.

Bardhan, P., Analytics of the institutions of informal cooperation in rural development, "World Development", Vol. 21(4), pp. 633-639, 1993. 
Baum, J., Oliver, C., Institutional Embeddedness and the Dynamics of Organizational Population, “American Sociological Review”, August 1, pp. 540-559, 1992.

Beritelli, P., Cooperation among prominent actors in a tourist destination, "Annals of Tourism Research", Vol. 38(2), pp. 607-629, 2011.

Bramwell, B., Lane, B., Editorial, "Journal of Sustainable Tourism”, Vol. 7(3\&4), pp. 179-181, 1999.

Burt, R.S., Structural Holes, Harvard University Press, Cambridge, 1992.

Casanueva, C., Gallego, Á., Sancho, M., Network resources and social capital in airline alliance portfolios, "Tourism Management", Vol. 36, pp. 441-453,2013.

Casanueva, C., Gallego, Á., García-Sánchez, M. R., Social network analysis in tourism, "Current Issues in Tourism", Vol. 19(12), pp. 1190-1209, 2016.

Crotts, J. C., Buhalis, D., March R., Global Alliances in Tourism and Hospitality Management.The Haworth Hospitality Press, An Imprint of The Haworth Press, Inc., New York-London-Oxford 2000.

Czernek, K., Determinants of cooperation in a tourist region, "Annals of Tourism Research", Vol. 40(1), pp. 83-104, 2013.

Czernek, K., The role of social embeddedness in tourist region cooperation, "European Journal of Tourism and Hospitality Research", Vol. 5(2), pp. 61-81, 2014.

Czernek, K., Tourism features as determinants of knowledge transfer in the process of tourist cooperation, "Current Issues in Tourism", Vol. 20(2), pp. 204-220, 2017.

Czernek, K., Czakon, W., Trust-building processes in tourist coopetition: The case of a Polish region, "Tourism Management", Vol. 52, pp. 380-394, 2016.

Dacin, M. T., Ventrusca, M., Beal, B., The embeddedness of organizations: dialogue and directions, "Journal of Management", Vol. 25(3), pp. 317-356, 1999.

Davidsson, P., Honig, B., The role of social and human capital among nascent entrepreneurs, "Journal of Business Venturing”, 18(3), pp. 301-331, 2003.

Dequech, D., Cognitive and cultural embeddedness: combining institutional economics and economic sociology, "Journal of Economic Issues", Vol. 37(2), pp. 461-470, 2003.

Domhoff, G. W., The Higher Circles. Random House, New York 1971.

Domínguez, S., Hollstein, B. (eds.), Mixed methods social networks research: Design and applications. Cambridge University Press, 2014.

Donckels, R., Lambrecht, J., The network position of small businesses: an explanatory model, "Journal of Small Business Management", April, pp. 65-97, 1997.

Dredge, D., Policy networks and the local organisation of tourism, "Tourism Management", Vol. 27(6), pp. 1192-1208, 2006.

Eisenhardt, K. M., Graebner, M. E., Theory building from cases: opportunities and challenges, "Academy of Management Journal", Vol. 50(1), pp. 25-32, 2007.

Ellis, P. D., Social ties and international entrepreneurship: Opportunities and constraints affecting firm internationalization, "Journal of International Business Studies", Vol. 42(1), pp. 99-127, 2011.

Freeman, L. C., Centrality in social networks conceptual clarification, "Social networks", Vol. 1(3), pp. 215-239, 1978. 
Fyall, A., Garrod, B., Tourism marketing: A collaborative approach. Channel View Publications, 2005.

Gargiulo, M., Benassi, M., Trapped in your own net? Network cohesion, structural holes, and the adaptation of social capital, "Organization Science”, Vol. 11(2), pp. 183-196, 2000.

Gephart, R. P., Qualitative Research and the Academy of Management Journal, "Academy of Management Journal", Vol. 47(4), pp. 454-462, 2004.

Getz, D., Jamal, T. B., The environment-community symbiosis: A case for collaborative tourism planning, "Journal of Sustainable Tourism", Vol. 2(3), pp. 152-17, 1994.

Gibbons, R., What is Economic Sociology and Should any Economists Care?, "Journal of Economic Perspectives", Vol. 19(1), pp. 3-7, 2005.

Gill, A., Williams, P., Managing growth in mountain tourism communities, "Tourism Management", Vol. 15(3), pp. 212-220, 1994.

Grabher, G., Rediscovering the social in the economics of interfirm relations, in: The Embedded Firm: On the Socio-Economics of Industrial Networks, ed. G. Grabher, pp. 1-31. Routledge, London, 1993.

Grangsjo,Y. v. F., Hotel networks and social capital in destination marketing, "International Journal of Service Industry Management”, Vol. 17(1), pp. 58-7, 2006.

Granovetter, M., Economic Action and Social Structure: The Problem of Embeddedness, “American Journal of Sociology", 91(3), pp. 481-510, 1985.

Granovetter, M., Problems of explanation in economic sociology [in:] Nohria, N., Eccles, R. (eds.). Networks and Organizations: Structure, Form and Action. Harvard Business School Press, Harvard 1993.

Granovetter, M., The Impact of Social Structure on Economic Outcomes, "Journal of Economic Perspectives", Vol. 19(1), pp. 33-50, 2005.

Gulati, R., Gargiulo M., Where Do Interoganizational Networks Come from?, "American Journal of Sociology", Vol. 104(5), pp. 1439-1493, 1999.

Gursoy, D., Saayman, M., Sotiriadis, M. (eds.), Collaboration in tourism businesses and destinations: A handbook. Emerald Group Publishing, 2015.

Håkansson, H., Snehota, I., 1.3 The IMP perspective: assets and liabilities of business relationships. Understanding business marketing and purchasing: an interaction approach, pp. 35-50, 2002.

Helper, S., Comparative supplier relations in the U.S. and Japanese auto industries: An exit voice approach, "Business Economic History", January, pp. 153-162, 1990.

Hibbert, J. F., Dickinson, J. E., Curtin, S., Understanding the influence of interpersonal relationships on identity and tourism travel, "An International Journal of Tourism and Hospitality Research", Vol. 24(1), pp. 30-39, 2013.

Hoang, H., Antoncic, B., Network-Based Research in Entrepreneurship: A Critical Review, "Journal of Business Venturing", Vol. 18(2), pp. 165-187, 2003.

Ingram, P., Roberts, P., Friendships Among Competitors in the Sydney Hotel Industry, "American Journal of Sociology", Vol. 106(2), pp. 387-423, 2000.

Jack, S. L., The Role, Use and Activation of Strong and Weak Network Ties: Qualitative Analysis, "Journal of Management Studies", Vol. 42(6), pp. 1249-1260, 2005. 
Jack, S. L., Approaches to studying networks: implications and outcomes, "Journal of Business Venturing", Vol. 25(1), pp. 120-137, 2010.

Jack, S. L., Anderson, A. R., The effects of embeddedness on the entrepreneurial process, "Journal of Business Venturing", Vol. 17(5), pp. 467-487, 2002.

Jack, S., Dodd, S. D., Anderson, A. R., Change and the development of entrepreneurial networks over time: a processual perspective, "Entrepreneurship \& Regional Development", 20 March, pp. 125-159, 2008.

Johannisson, B., Beyond process and structure: social exchange networks, "International Studies of Management and Organisation”, Vol. 17(1), pp. 3-23, 1987.

Johannisson, B., Mőnsted, M., Contextualizing entrepreneurial networking, "International Journal of Management and Organization”, Vol. 27(3), pp. 109-136,1997.

Jones, C., Hesterly, W. S., Borgatti, S. P., A general theory of network governance: exchange conditions and social mechanisms, "Academy of Management Review", Vol. 22(4), pp. 911-946, 1997.

Kelman, I., Luthe, T., Wyss, R., Tørnblad, S. H., Evers, Y., Curran, Williams, R. J., Berlow, E. L, Social network analysis and qualitative interviews for assessing geographic characteristics of tourism business networks, "ploS one", Vol. 11(6), 2016.

Koestler, A. The Act of Creation. Hutchinson, London 1964.

Krippner, G. R., Alvarez, A. S., Embeddedness and the Intellectual Projects of Economic Sociology, "Annual Review of Sociology", 33, pp. 219-240, 2007.

Lee, Y., Cavusgil, S. T., Enhancing alliance performance. The effects of contractual-based versus relational-based governance, "Journal of Business Research", Vol. 59(8), pp. 896-905, 2006.

Lee, S. H., Choi, J. Y., Yoo, S. H., Oh, Y. G., Evaluating spatial centrality for integrated tourism management in rural areas using GIS and network analysis, "Tourism Management”, Vol. 34, pp. 14-24, 2013.

Leung, X. Y., Wang, F., Wu, B., Bai, B., Stahura, K. A., Xie, Z., A social network analysis of overseas tourist movement patterns in Beijing: The impact of the Olympic Games, "International Journal of Tourism Research", Vol. 14(5), pp. 469-484, 2012.

Leung, D., Li, G., Fong, L. H. N., Law, R., Lo, A., Current state of China tourism research, "Current Issues in Tourism" Vol. 17(8), pp. 679-704, 2014.

Locke, R., Jacoby W., The dilemmas of diffusion: social embeddedness and the problems of institutional change in Eastern Germany, "Politics and Society", vol. 25(1), pp. 34-65, 1997.

Larson, A., Network dyads in entrepreneurial settings: A study of the governance of exchange processes, “Administrative Science Quarterly”, Vol. 37, pp. 76-104, 1992.

Lechner, C., Dowling, M., Firm networks: external relationships as sources for the growth and competitiveness of entrepreneurial firms, "Entrepreneurship \& Regional Development", Vol. 15(1), pp. 1-26, 2003.

Merinero-Rodríguez, R., Pulido-Fernández, J. I., Analysing relationships in tourism: A review, “Tourism Management", Vol. 54, pp. 122-135, 2016.

Mason, J., Qualitative Researching. Sage, London 1996. 
McDade, B. E., Spring, A., The new generation of African entrepreneurs: networking to change the climate for business and private sector-led development, "Entrepreneurship and Regional Development", Vol. 17(1), pp. 17-42, 2005.

Miles, M. B., Huberman, A. M., Analiza danych jakościowych [Qualitative data analysis]. TRANS HUMANA, Białystok 2000.

Mitręga, M., Zolkiewski, J., Negative consequences of deep relationships with suppliers: An exploratory study in Poland, "Industrial Marketing Management", Vol. 41(5), pp. 886894, 2012.

Mizruchi, M., Stearns, L. B., A longitudinal study of borrowing by large American corporations, "Administrative Science Quarterly", Vol. 39, pp. 118-140, 1994.

Mizruchi, M., Stearns, L. B., Getting deals done: the use of social networks in bank decisionmaking, "American Sociological Review", Vol. 66(5), pp. 647-672, 2001.

Mizruchi, M., Conditional Nature of Embeddedness: A Study of Borrowing by Large U.S. Firms, “American Sociological Review”, Vol. 71(2), pp. 310-333, 2006.

Moorman, C., Zaltman, G., Deshpande R., Relationship between Providers and Users of Marketing Research: The Dynamics of Trust within and between Organizations, "Journal of Marketing Research", Vol. 29(3), pp. 314-328, 1992.

Munar, A. M., Jacobsen, J. S., Trust and Involvement in Tourism Social Media and Web-Based Travel Information Sources, "Scandinavian Journal of Hospitality and Tourism", Vol. 13(1), pp. 1-19, 2013.

Nahapiet, J., Ghoshal, S., Social capital, intellectual capital, and the organizational advantage, “Academy of Management Review", Vol. 23(2), pp. 242-266, 1998.

Nunkoo, R., Ramkisson, H., Power, trust, social exchange and community support, "Annals of Tourism Research", Vol. 39(3), pp. 1538-1564, 2011a.

Nunkoo, R., Ramkissoon, H., Developing a community support model for tourism, “Annals of Tourism Research", Vol. 38(3), pp. 964-988, 2011 b.

Pavlovich, K., The evolution and transformation of a tourism destination network: the Waitomo Caves, New Zealand, “Tourism Management”, Vol. 24(2), pp. 203-216, 2003.

Peng, M. W., Lee, S.-H., Wang, D. Y. L., What determines the scope of the firm over time: a focus on institutional relatedness, "Academy of Management Review", 30(3), pp. 622-633, 2005.

Peterson, M., Rajan, R., The benefits of lending relationships: Evidence from small business data, "Journal of Finance", Vol. 49(1), pp. 3-37, 1994.

Piore, M., The social embeddedness of the labour market and cognitive processes, "Labour" Vol. 7(3), pp. 3-18, 1993.

Poppo, L., Zenger, T., Do formal contracts and relational governance function as substitutes or complements?, "Strategic Management Journal”, Vol. 23(8), pp. 707-725, 2002.

Portes, A., Sensenbrenner, J., Embeddedness and immigration: notes on the social determinants of economic action, "American Journal of Sociology", Vol. 98(6), pp. 1320-1350, 1993.

Powell, W. W., Neither market nor hierarchy: network forms of organization [in:] Straw, B., Cummings, L. L. (eds.), Research in Organizational Behaviour. CT: JAI Press, Greenwich 1990. 
Rachela, P., Hu, C., A Social network perspective of tourism research collaborations, "Annals of Tourism Research", Vol. 37(4), pp. 1012-1034, 2010.

Reed, M. G., Power Relations and Community-Based Tourism Planning, "Annals of Tourism Research", Vol. 24(3), pp. 566-591, 1997.

Reed, M. G., Collaborative Tourism Planning as Adaptive Experiments in Emergent Tourism Settings, "Journal of Sustainable Tourism", Vol. 7(3-4), pp. 331-355, 1999.

Ring, P. S., Van de Ven, A. H., Structuring cooperative relationships between organizations, "Strategic Management Journal", Vol. 13(7), pp. 483-498, 1992.

Ritchie, R. B., Ritchie, B., A Framework for an Industry Supported Destination Marketing Information System, “Tourism Management”, Vol. 23(5), pp. 439-454, 2002.

Robson, J., Robson, K., From shareholders to stakeholders: Critical issues for tourism marketers, "Tourism Management", Vol. 17(7), pp. 533-540, 1996.

Rodriguez, C., Langley, A., Beland, F., Denis, J. L., Governance, power, and mandated collaboration in an interorganizational network, "Administration \& Society", Vol. 39(2), pp. 150-193, 2007.

Smith, S., How Big, How Many? Enterprise Size Distributions in Tourism and Other Industries, "Journal of Travel Research", Vol. 45 (1), pp. 53-58, 2006.

Romeiro, P., Costa, C., The potential of management networks in the innovation and competitiveness of rural tourism: a case study on the Valle del Jerte (Spain), "Current Issues in Tourism", Vol. 13(1), pp. 75-91, 2010.

Rowley, T., Behrens. D, Krackhardt, D., Redundant governance structures: an analysis of structural and relational embeddedness in the steel and semiconductor industries, "Strategic Management Journal", Vol. 21(3), pp. 396-386, 2000.

Rutashobya, L., Jaensson, J. E., Small firms' internationalization for development in Tanzania: Exploring the network phenomenon, "International Journal of Social Economics", Vol. 31(1/2), pp. 159-172, 2004.

Saxena, G., Beyond mistrust and competition - the role of social and personal bonding pro-cesses in sustaining livelihoods of rural tourism businesses: A case of the Peak District National Park, "International Journal of Tourism Research", Vol. 8(4), pp. 263-277, 2006.

Schaffer, V., Lawley, M., An analysis of the networks evolving from an artificial reef development, "Current Issues in Tourism", Vol. 15(5), pp. 497-503, 2012.

Scott, N., Baggio, R., Cooper, C. (eds.), Network Analysis and Tourism, From Theory to Practice. Channel View Publications, Clevedon-Buffalo-Toronto 2008.

Shih, H., Network characteristics of drive tourism destinations: An application of network analysis in tourism, "Tourism Management”, Vol. 27(5), pp. 1053-1063, 2006.

Siggelkow, N., Persuasion with case studies, “Academy of Management Journal”, Vol. 50(1), pp. 20-24, 2007.

Suddaby, R., What grounded theory is not, “Academy of Management Journal”, Vol. 49(4), pp. 633-642, 2006.

Snow, C. C., Miles, R. E., Coleman, H. J., Managing $21^{\text {st }}$ century network organizations, "Organizational Dynamics", Vol. 20(3), pp. 5-20, 1992.

Strobl, A., Peters, M., Entrepreneurial reputation in destination networks, “Annals of Tourism Research", Vol. 40(1), pp. 59-82, 2013. 
Timothy, D .J., Cooperative tourism planning in a developing destination, "Journal of Sustainable Tourism", Vol. 6(1), pp. 52-68, 1998.

Tinsley, R., Lynch, P., Small tourism business networks and destination development, "International Journal of Hospitality Management", Vol. 20(4), pp. 367-378, 2001.

Tsai, M. C., State Power, State Embeddedness, and National Development in less Developed Countries: A Cross-National Analysis, "Studies in Comparative International Development", Vol. 33(4), pp. 66-88, 1999.

Useem, M., The Social Organization of the American Business Elite and Participation of Corporation Directors in the Governance of American Institutions, "American Sociological Review", Vol. 44, pp. 553-572, 1979.

Uzzi, B, The Sources and Consequences of Embeddedness for the Economic Performance of Organizations: the Network Effects, "American Sociological Review", Vol. 61(4), pp. 674-698, 1996.

Uzzi, B., Social Structure and Competition in Interfirm Networks: The Paradox of Embeddedness, “Administrative Science Quarterly”, Vol. 42(1), pp. 35-67, 1997.

Uzzi, B., Lancaster, R., Embeddedness and price formation in the corporate law market, "American Sociological Review", Vol. 69(3), pp. 319-344, 2004.

Wang, Y., Fesenmaier, D. R., Collaborative destination marketing: A case study of Elkhart county, Indiana, “Tourism Management”, Vol. 28(3), pp. 863-875, 2007.

Wasserman, S., Faust, K., Social network analysis: Methods and applications (Vol. 8). Cambridge University Press, Cambridge 1994.

Webster, F., Wind, Y., Organizational Buying Behavior. N.J.: Prentice-Hall, Englewood Cliffs, 1972.

Zukin, S., DiMaggio, P., Structures of Capital. The Social Organisation of the Economy. Cambridge University Press, Cambridge 1990.

Received: February 2018

Acknowledgment: The project was financed from funds of National Science Centre in Poland according to decision UMO-2017/27/B/HS4/01051 (Katarzyna Czernek-Marszatek) and from the interdepartmental grant of the Poznan University of Economics and Business: 'New research directions in the field of economic sciences'; the project: 'The future of money - cryptocurrencies, local currencies and cashless society' (Pawet Marszatek). 


\section{APPENDIX}

Table 1

Interviewee characteristics

\begin{tabular}{|c|c|}
\hline Form of ownership & $\begin{array}{l}\text { - private one-person company }-67 \% \\
\text { - private venture }-27 \% \text { (mainly Ltd) } \\
\text { - other forms }-6 \% \text { (an institution supported by an endowment, a state } \\
\text { treasury company, or a public company) } \\
\end{array}$ \\
\hline Company size & $\begin{array}{l}\text { - micro (up to } 9 \text { employees) }-81 \% \\
\text { - small (10-49 employees) }-15 \% \\
- \text { medium }(50-249)-4 \%\end{array}$ \\
\hline $\begin{array}{l}\text { Date of company } \\
\text { establishment }\end{array}$ & $\begin{array}{l}\text { - before } 1989-15 \% \\
-1990-2000-31 \% \\
-2001-2013-54 \% \\
\end{array}$ \\
\hline $\begin{array}{l}\text { Date of first WTO } \\
\text { membership }\end{array}$ & $\begin{array}{l}- \text { in } 2008-58 \% \\
\text { - later than } 2008-42 \% \\
\end{array}$ \\
\hline $\begin{array}{l}\text { Interviewee } \\
\text { position occupied }\end{array}$ & $\begin{array}{l}- \text { owner }-75 \% \\
\text { - employee }-25 \% \text { (marketing director, company manager, in the local } \\
\text { government -the head of the Tourism Culture and Sport Promotion } \\
\text { Department) }\end{array}$ \\
\hline Gender & $\begin{array}{l}\text { - male }-42 \% \\
- \text { female }-58 \% \\
\end{array}$ \\
\hline Age & $\begin{array}{l}-18-25-0 \% \\
-26-40-33.33 \% \\
-41-65-58.33 \% \\
- \text { over } 65-8.33 \% \\
\end{array}$ \\
\hline Education & $\begin{array}{l}\text { - primary }-2 \% \\
\text { - vocational } 10 \% \\
\text { - upper secondary }-42 \% \\
\text { - higher }-46 \%\end{array}$ \\
\hline $\begin{array}{l}\text { Interviewee place } \\
\text { of origin }\end{array}$ & $\begin{array}{l}\text { - Wisła }(50 \%) \\
\text { - outside }(37,5 \%) \\
\text { - the owner from the outside, but spouse from Wisła }(12.5 \%)\end{array}$ \\
\hline
\end{tabular}

Source: own elaboration. 
Table 2

Centrality of actors in the network of business cooperation

\begin{tabular}{|c|c|c|c|c|c|}
\hline Actor & Outdegree & Indegree & Out-closeness & In-closeness & Betweenness \\
\hline 1 & 12 & 3 & 94 & 108 & 4.386 \\
\hline 2 & 8 & 8 & 96 & 98 & 10.045 \\
\hline 3 & 15 & 9 & 89 & 97 & 51.671 \\
\hline 4 & 2 & 4 & 108 & 108 & 0.356 \\
\hline 5 & 3 & 11 & 108 & 93 & 35.870 \\
\hline 6 & 3 & 0 & 135 & 235 & 0.000 \\
\hline 7 & 0 & 3 & 235 & 135 & 0.000 \\
\hline 8 & 7 & 8 & 99 & 95 & 62.541 \\
\hline 9 & 9 & 6 & 99 & 105 & 1.398 \\
\hline 10 & 7 & 15 & 100 & 88 & 21.052 \\
\hline 11 & 10 & 8 & 96 & 101 & 3.076 \\
\hline 12 & 10 & 11 & 98 & 97 & 7.474 \\
\hline 13 & 20 & 17 & 82 & 87 & 97.154 \\
\hline 14 & 14 & 19 & 96 & 85 & 108.667 \\
\hline 15 & 13 & 9 & 91 & 98 & 14.654 \\
\hline 16 & 6 & 19 & 99 & 83 & 32.676 \\
\hline 17 & 5 & 15 & 100 & 89 & 16.214 \\
\hline 18 & 21 & 14 & 82 & 92 & 126.801 \\
\hline 19 & 7 & 10 & 97 & 97 & 17.466 \\
\hline 20 & 10 & 5 & 96 & 100 & 4.793 \\
\hline 21 & 11 & 7 & 94 & 101 & 13.061 \\
\hline 22 & 5 & 1 & 110 & 136 & 0.111 \\
\hline 23 & 12 & 3 & 94 & 106 & 3.122 \\
\hline 24 & 13 & 2 & 88 & 139 & 12.901 \\
\hline 25 & 5 & 10 & 110 & 95 & 6.003 \\
\hline 26 & 1 & 1 & 121 & 120 & 0.000 \\
\hline 27 & 2 & 1 & 139 & 231 & 0.000 \\
\hline 28 & 6 & 3 & 100 & 103 & 1.873 \\
\hline 29 & 35 & 24 & 65 & 77 & 475.878 \\
\hline 30 & 1 & 3 & 137 & 129 & 0.250 \\
\hline 31 & 4 & 2 & 105 & 133 & 0.816 \\
\hline 32 & 1 & 1 & 142 & 120 & 0.000 \\
\hline 33 & 12 & 4 & 92 & 109 & 25.397 \\
\hline 34 & 9 & 3 & 99 & 127 & 10.470 \\
\hline 35 & 13 & 16 & 89 & 85 & 61.623 \\
\hline 36 & 15 & 12 & 88 & 95 & 34.287 \\
\hline 37 & 8 & 6 & 103 & 99 & 31.952 \\
\hline 38 & 2 & 7 & 121 & 104 & 3.545 \\
\hline 39 & 11 & 12 & 93 & 92 & 99.643 \\
\hline 40 & 7 & 7 & 95 & 100 & 64.313 \\
\hline 41 & 4 & 4 & 113 & 110 & 9.196 \\
\hline 42 & 18 & 13 & 84 & 92 & 148.837 \\
\hline 43 & 0 & 5 & 235 & 98 & 0.000 \\
\hline 44 & 22 & 32 & 78 & 69 & 369.300 \\
\hline 45 & 4 & 14 & 103 & 88 & 60.851 \\
\hline 46 & 9 & 12 & 101 & 94 & 25.062 \\
\hline 47 & 15 & 21 & 90 & 82 & 66.214 \\
\hline 48 & 1 & 8 & 140 & 104 & 0.000 \\
\hline
\end{tabular}

Source: author's own work. 